Terr. Atmos. Ocean. Sci., Vol. 18, No. 2, 183-221, June 2007

\title{
Structural, Mineralogical, and Geochemical Characterization of the Chelungpu Thrust Fault, Taiwan
}

\author{
Angela J. Isaacs ${ }^{1,2}$, James P. Evans ${ }^{1, *}$, Sheng-Rong Song ${ }^{3}$, and Peter T. Kolesar ${ }^{1}$
}

(Manuscript received 30 July 2005, in final form 8 March 2007)

\begin{abstract}
The Chelungpu fault, Taiwan, produced a northward propagating rupture on 21 September 1999 resulting in a $M_{w} 7.6$ earthquake with a $\sim 90 \mathrm{~km}$ long N-S trending fault scarp. The mineralogic and physical character of the fault-related rocks within the Chelungpu fault zone, as measured at 9 sites along $70 \mathrm{~km}$ of the 1999 rupture trace, changes significantly along strike and with depth. The northern section of the Chelungpu fault has a 10 - $30 \mathrm{~m}$-wide primary damage zone that is characterized by increased fracture density and alteration, but little microstructural damage to within $\mathbf{1 ~} \mathbf{m}$ from the main fault. The southern section of the Chelungpu fault has a $25-70 \mathrm{~m}$ wide primary damage zone that is characterized by increased fracture density and alteration, the presence of intensely sheared rock, and numerous secondary faults and gouge zones as far as $\mathbf{2 4 0} \mathrm{m}$ from the main fault. The complexity of the damage zone, geochemistry, and clay mineralogy of the southern fault zone may reflect its relative maturity ( 1 Ma) compared to the northern fault zone ( $46-100 \mathrm{Ka})$. The major down-dip mineralogic variation is a transition from a significant amount of smectite in exhumed fault cores to little or no smectite in the fault core at sampled depths of 200 to $1000 \mathrm{~m}$. This transition may be influenced by weathering processes at the surface, however co-seismic fluid flow may have a role in illite-smectite reactions. The composition of clays has important seismologic implications as clays play a role in fault weakening.
\end{abstract}

(Key words: Faults, Composition, Structure, Geochemistry, Mineralogy)

\footnotetext{
${ }^{1}$ Department of Geology, Utah State University, Logan, UT, USA

2 Anadarko Petroleum Corporation, Denver, CO, USA

3 Department of Geosciences, National Taiwan University, Taipei, Taiwan, ROC

* Corresponding author address: Dr. James P. Evans, Department of Geology, Utah State University, Logan, UT, USA; E-mail: jpevans@cc.usu.edu doi: 10.3319/TAO.2007.18.2.183(TCDP)
} 


\section{INTRODUCTION}

\subsection{Fault Zone Structure and Composition}

The structure and composition of the near-surface portion of brittle fault zones can be divided into three components: fault core, damage zone, and protolith (Chester and Logan 1986; Chester et al. 1993, 2004; Evans and Chester 1995; Caine et al. 1996; Wilson et al. 2003). The fault core is the portion of the fault zone that accommodates the most slip and reflects high shear strain. It is typically characterized by geochemically altered and comminuted rocks such as fault gouge and ranges from millimeters to meters thick (Chester et al. 1993; Caine et al. 1996). Clay fault gouge is a clay-rich dominated, low-temperature fault rock (Vrolijk and van der Pluijm 1999) that develops due to brittle deformation such as cataclasis associated with near-surface faulting (Scholz 1989; Sibson 1977) and alteration of the protolith (Goddard and Evans 1995; Caine and Forester 1999; Vrolijk and van der Pluijm 1999; Solum et al. 2005). Phyllosilicates in the fault core have been identified by many workers as an important mechanism for fault weakening (Wu 1978; Chester et al. 1993; Evans and Chester 1995; Wintsch et al. 1995; Schleicher et al. 2006; Solum et al. 2006). Smectite has been documented as a major constituent of fault gouge (Wu 1978; Chester and Logan 1986; Solum et al. 2003; Jacobs et al. 2006) as has illite (Vrolijk and van der Pluijm 1999; Solum et al. 2005) and other clays including chlorite and kaolinite (Solum et al. 2003; this study).

The fault core is surrounded by a damage zone that is characterized by an increased density of subsidiary faults, fractures, veins, foliation, and folding relative to the host rock (Chester and Logan 1986; Caine et al. 1996). The damage zone records deformation inherited from past fault motion, presumably by repeated earthquakes (Chester and Logan 1986; Caine et al. 1996; Schulz and Evans 1998). The damage zone can further be divided into the primary damage zone (PDZ) and the secondary damage zone (SDZ; Jacobs et al. 2006). The primary damage zone surrounds the fault core and can have a dense network of fractures and secondary faults that may obscure the original rock structure. The primary damage zone can exhibit significant chemical alteration as compared to the host rock, whereas the composition of the secondary damage zone more closely approximates the host rock. The secondary damage zone surrounds the fault core and primary damage zone and contains deformation associated with faulting, but with less intensity than the primary damage zone. The host rock, or protolith, enclosing the fault core and damage zone is basically undamaged by faulting, but may contain regional structures and is an important control for background deformation structures and composition.

Evaluation of fault zone structures and composition provides insight into issues of fluid flow, fault strength, and fault maturity or accumulated damage on a fault. Shale- and clay-rich fault zones are not typically well preserved because they weather easily, and are therefore not well studied at the microstructural and outcrop scale. The Chelungpu fault provides a valuable opportunity to characterize shale- and clay-rich fault zones. Seismic models and earthquake physics studies require data of the type provided by this study (Ide and Beroza 2001; Spudich and Olsen 2001). Data presented in this study provides an important characterization of the Chelungpu fault and can be used as a geologic basis for models of fluid flow properties of shale- and clay-rich faults and energy distribution of faults. 


\subsection{Study Area}

The Chelungpu thrust fault (CLF) is part of the fold-and-thrust belt of the western Taiwan orogen (Fig. 1; Chen and Kao 2000) that cuts shallow marine upper Miocene and Pliocene siltstone, shale, and sandstone of the Kueichulin, Chinshui, and Cholan Formations (Covey 1984). Near the surface, the fault dips to the east $52^{\circ}$ to $60^{\circ}$ along the northern segment and places siltstones of the Chinshui and Kueichulin Formations on Quaternary gravels and siltstones of the Chinshui or Kueichulin Formation (Lee et al. 2001; Heermance et al. 2003). The Chelungpu fault flattens overall to approximately $25^{\circ}-35^{\circ} \mathrm{E}$ in the southern segment (Kao and Chen 2000; Heermance et al. 2003; Wang et al. 2007) and places siltstones of the Chinshui and Kueichulin Formations on Quaternary gravels and Pleistocene Toukoshan gravels (Heermance 2002; Tanaka et al. 2002). An exception to this moderate dip in the fault is the southern terminus of the Chelungpu fault, where the fault is steeply dipping. The northern segment has an overall hanging wall flat on footwall flat geometry, whereas the southern segment has an overall hanging wall flat on footwall ramp geometry (Heermance et al. 2003). Locally, the Chelungpu fault is observed to cut across bedding; thus, the fault does not strictly have a hanging wall flat geometry.

The 21 September $1999 \mathrm{M}_{\mathrm{w}} 7.6$ earthquake produced a northward propagating rupture resulting in an $\sim 90 \mathrm{~km}$ long north-south trending surface rupture on the Chelungpu fault (Ma et al. 2000; Chen et al. 2001). Co-seismic slip increased northward along the fault trace with an average throw of $2 \mathrm{~m}$ on the southern section of the fault as compared to a throw of $5-7$ and $7-9 \mathrm{~m}$ of horizontal displacement on the northern segment of the fault (Ma et al. 2000; Chen et al. 2001; Lin et al. 2001). Strong ground motion, including high frequency acceleration and rupture velocity, decreased from south to north (Lin et al. 2001). The displacement was nearly pure thrust slip near the epicenter in the southern portion of the fault, and changed to oblique thrust with a strong left-lateral component in the north (Chen et al. 2001; Dalguer et al. 2001; Lin et al. 2001). To the north, the rupture occurred in the hanging wall of an older fault strand called the Sanyi fault, whereas the rupture remained on the older established Chelungpu fault to the south (Fig. 1; Ho and Chen 2000; Heermance et al. 2003). The new northern strand of the fault has so little displacement that rocks in the footwall and hanging wall are in their original stratigraphic order across the fault at depth.

We compare and examine portions of core intersecting the Chelungpu fault zone and detailed transects and samples from 6 field sites (from 15 to $300 \mathrm{~m}$ long) to determine fault structure and composition (Fig. 1). Host rock samples were collected from the TCDP core primarily to provide a geochemical and mineralogical standard for comparison with samples from the exhumed fault zone at field sites. The locations of field sites and drill sites are shown on the in Fig. 1 and referenced in the text using the TW67 coordinate system.

\subsection{Previous Work}

This study incorporates physical, mineralogical and geochemical data from previous and current studies of 3 drill holes; the Fengyuan, Nantou, and the Taiwan Chelungpu-fault Drilling Project (TCDP). Background data for field sites and drill sites, including fault orientation and offset, are listed in Table 1. 

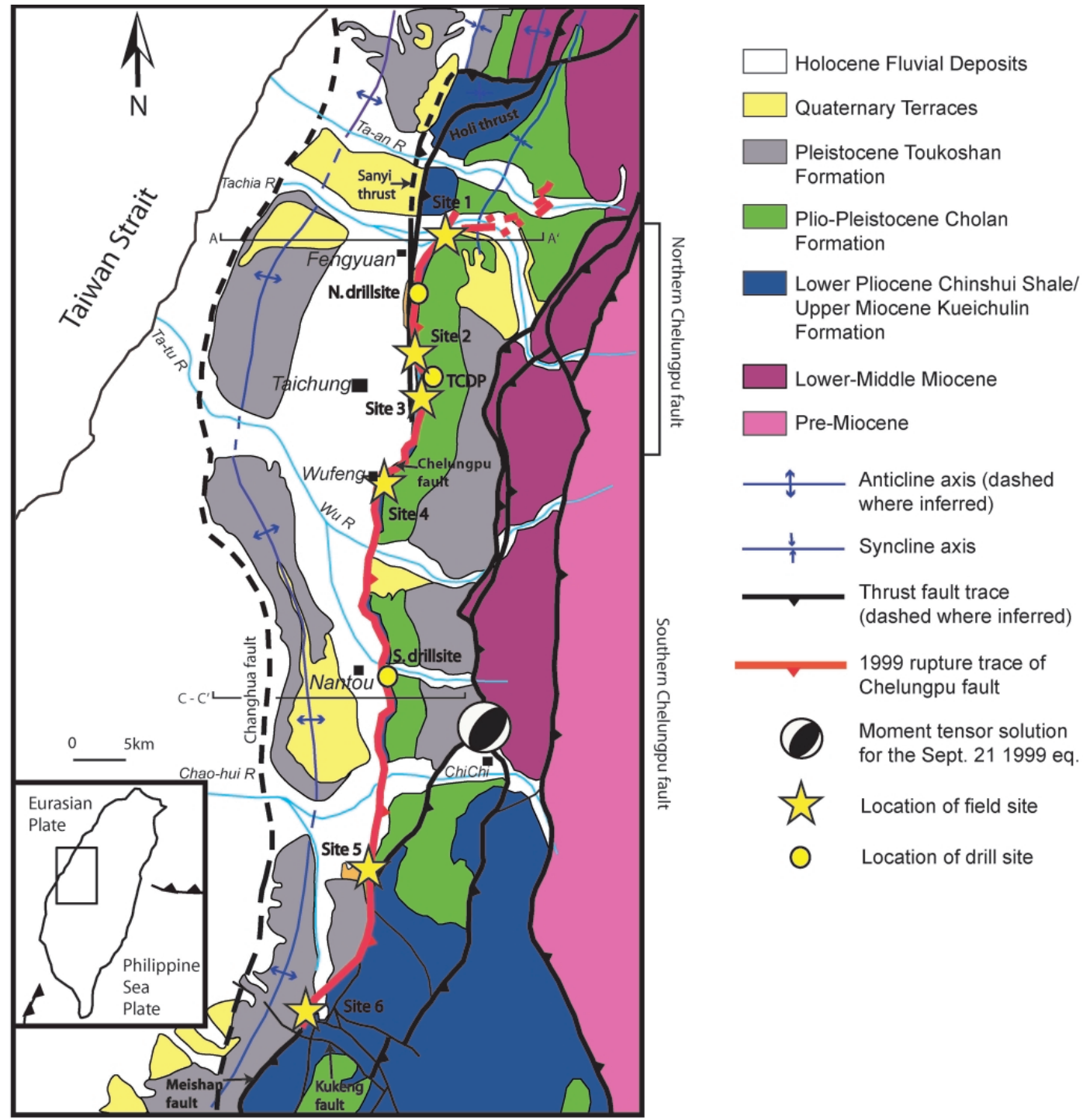

Fig. 1. Geologic map of the Chelungpu fault area and the extent of the 21 September 1999 rupture. Additional west vergent faults are shown. Map modified from Chui (1971), Lin et al. (2001), and Heermance et al. (2003).

\subsubsection{Northern Drillsite: Fengyuan}

At the northern drillsite, the largest fracture zone was located within the Kueichulin Formation from 285.40 to $327.6 \mathrm{~m}$ measured depth along the borehole (Heermance et al. 2003). 
The lower $1.5 \mathrm{~m}$ of this zone has the highest fracture density of the entire borehole. At the base is a $7 \mathrm{~mm}$-thick fault gouge, which is determined to be the primary slip surface of the 1999 rupture (Heermance 2002; Heermance et al. 2003). The Fengyuan core shows a normal stratigraphic sequence across the Chelungpu fault; good evidence for a youthful fault in this area (Heermance et al. 2003). Thin sections of samples from the Fengyuan drill core show little foliation or other microstructures within $2 \mathrm{~m}$ of the main fault. Foliation is not well developed in the fine-grained matrix of random fabric fault breccia surrounding the Chelungpu fault (Heermance et al. 2003). Fault rocks consist of quartz, feldspar, and combinations of illite, kaolinite, chlorite, and smectite clays in samples collected from secondary fault gouge and surrounding wall rock at depths of $\sim 222$ - $330 \mathrm{~m}$ along the borehole (Liao 2003). While smectite is detected in most samples, it is either absent from fault gouge samples or reduced relative to the surrounding wall rock, having been replaced by illite and I-S (Liao 2003). The concentration of measured oxides is decreased in fault gouge relative to host rocks, with $\mathrm{CaO}$ being the most depleted, and $\mathrm{MgO}$ and $\mathrm{SiO}_{2}$ also significantly depleted (Liao 2003).

\subsubsection{Southern Drillsite: Nantou}

At the southern drillsite, the widest fracture zone was located from 153.8 to $176.8 \mathrm{~m}$ depth and is characterized by foliated fault breccia. The base of this fracture zone consists of $1.1 \mathrm{~m}$

Table 1. Number of field and core samples used for optical microscopy and analyzed by XRD, XRF, and/or ICP MS in this study.

\begin{tabular}{ccccc} 
Study Site & Thin Sections & Bulk XRD & Clay XRD & XRF/ICP \\
\hline \multicolumn{5}{c}{ FIELD SITES } \\
\hline Field Site 1 & 3 & 9 & 5 & \\
Field Site 2 & 0 & 0 & 8 & 0 \\
Field Site 3 & 7 & 18 & 9 & 9 \\
Field Site 4 & 9 & 33 & 9 & 17 \\
Field Site 5 & 2 & 22 & 4 & 6 \\
Field Site 6 & 11 & 24 & 11 & 14
\end{tabular}

DRILL SITES

\begin{tabular}{lcccc}
\hline Fengyuan & 0 & $?$ & $25^{*}$ & $12^{*}$ \\
Nantou & 0 & $?$ & $74^{*}$ & $12^{*}$ \\
TCDP & 8 & 8 & 4 & 8
\end{tabular}

* these samples were analyzed in previous studies by Liao 2003 and Lu 2004. Results are used for this study 
of foliated fault gouge above a dark gray, fine-grained fragile material with angular grains and a random fabric (Heermance 2002; Tanaka et al. 2002). In the $70 \mathrm{~m}$ of core above the foliated gouge, there is less than $15 \mathrm{~m}$ of undeformed shale (Heermance 2002). Quantitative XRD indicates that illite and kaolinite become increasingly enriched from host rock to damage zone to fault gouge, and that smectite and chlorite become increasingly depleted from host rock to fault gouge ( $\mathrm{Lu}$ 2004). Smectite is absent in some secondary fault gouge samples (Lu 2004). As determined by XRF, the concentrations of $\mathrm{NaO}, \mathrm{SiO}_{2}$, and $\mathrm{CaO}$ are most depleted in fault gouge relative to the host rock (Lu 2004).

\subsubsection{Taiwan Chelungpu-Fault Drilling Project (TCDP): Taichung}

At the TCDP drillsite, a fault zone at $1111 \mathrm{~m}$ depth is interpreted as the 1999 slip surface (for example, Hung and Ma 2006; Hung et al. 2007; Sone et al. 2005, 2007; Yeh et al. 2007). This fault zone contains $<1 \mathrm{~m}$ of light gray, wet, massive clay that grades into $\sim 10-15 \mathrm{~cm}$ of foliated fault gouge. At the base of the foliated clay gouge is a $12 \mathrm{~cm}$ section of black fault gouge including several cm-thick layers of hard, brittle, black material (Hirono et al. 2006). This material was split in the core when it came out of the casing, and slicken lines were observed on the inside surface. Below the black material is $\sim 10-15 \mathrm{~cm}$ of clay gouge and drilling mud followed by a brecciated zone that is $\sim 20 \mathrm{~cm}$ thick. Preliminary clay mineralogy has identified illite, kaolinite, chlorite, smectite, and possibly R1 I-S in the fault gouge, (L. W. Kuo and J. G. Solum, pers. comm.). With this exception of one sample, illite is more abundant and smectite is less abundant in fault gouge relative to wall rocks (L. W. Kuo, pers. comm.).

\subsubsection{Field Site 2: Tali River (222105 E, 2674552 N)}

Heermance et al. $(2002,2003)$ describe a temporary outcrop exposed by excavation north of Taichung city and $6 \mathrm{~km}$ south of the Fengyuan drillsite. The fault core consists of a 20-cm thick clay gouge in sharp contact with the surrounding damage zone rocks. The primary damage zone is $\sim 30 \mathrm{~m}$ wide and is characterized by dense fractures and no relict bedding. Two secondary faults were identified in the hanging wall with $<1 \mathrm{~m}$ of throw. Microstructures include thin parted surfaces which are proposed to be the slip surfaces within the foliated fault gouge. Mineralogy results reported in previous work for all drill sites and Field site 2 were obtained from bulk powder and clay separates analyses.

\subsection{Field Methods}

To determine the structure and composition of the fault zone, a transect sampling method was employed for all outcrop sites in this study. Rock samples were collected for laboratory analysis at a maximum spacing of $5 \mathrm{~m}$ throughout the exposed fault zone. Sample density was smaller near the faults to increase data collection in areas of potential interest. Structural samples of fault gouge were oriented and collected for petrographic analysis. Weathered rock was cleared away before samples were taken. The width of the fault core is defined by the distance from the fault plane to the edges of the fault gouge. Fault gouge is recognized in the field as a 
tacky, clay-rich material with nearly-ductile behavior when wet. It is often foliated and sheared, and typically distinguishable from the surrounding wall rock by its appearance, feel, and often color. The width of the primary damage zone is defined by the transect length from the outside edge of the fault core to a significant decrease in density of macroscopic damage elements. The change from primary damage zone to secondary damage zone is marked by any combination of: the appearance of bedding, a notable decrease in fracture density, color changes, decrease in alteration, decrease in the amount of subsidiary faults, fault gouge and shear zones, and changes in the dominant type of deformation. Both the width of fault core and the width of the primary damage zone are measured only for the hanging wall rocks. Footwall rocks of the Chelungpu fault at the surface are typically gravel and show little recognizable damage because of their unconsolidated nature.

Field sites are described and numbered from north to south. Samples collected along a transect line at field sites are designated in two parts: 1) the component of the fault zone to which each sample belongs, including the main fault or fault core (FC), fault gouge in subsidiary faults (FG), primary damage zone (PDZ), and secondary damage zone (SDZ), and 2) the numerical distance that each sample was collected from the main fault trace, which is set at a value of zero. For example, FC $0+0$ is a sample collected from fault core of the main fault, FG $0+3$ is fault gouge collected from a secondary fault located $3 \mathrm{~m}$ into the hanging wall of the main fault trace, and PDZ $0+5$ is a sample taken from the primary damage zone $5 \mathrm{~m}$ into the hanging wall along the line of transect. The number of samples used for laboratory analyses for each study site is listed in Table 2 .

Table 2. Background information for field and drill sites (Chen and Lin 1999; Lin et al. 2005; this study).

\begin{tabular}{llll} 
Field Sites & Orientation of fault & Offset & Lithology \\
\hline Field Site 1 & $050^{\circ}, 40^{\circ} \mathrm{SE}$ & $8-11 \mathrm{~m}$ (throw) & Chinshui/Chinshui \\
Field Site 2 & $320^{\circ}, 48^{\circ} \mathrm{E}$ & $7 \mathrm{~m}$ (displacement) & Chinshui or Kueichulin/gravel \\
Field Site 3 & $040^{\circ}, 35^{\circ} \mathrm{E}$ & $6 \mathrm{~m}$ (displacement) & Chinshui or Keichulin/gravel \\
Field Site 4 & $040^{\circ}, 25^{\circ} \mathrm{E}$ & $2 \mathrm{~m}$ (throw) & Chinshui/gravel \\
Field Site 5 & & $1.5 \mathrm{~m}$ (throw) & Chinshui/gravel \\
Field Site 6 & $030^{\circ}, 80^{\circ} \mathrm{E}$ & $2 \mathrm{~m}$ (right-lateral) & Chinshui or Kueichulin/Toukoshan \\
Drill Sites & Orientation of fault $^{\circ}$ & Offset & Lithology \\
\hline Fengyuan & $340^{\circ}, 52^{\circ} \mathrm{SE}$ & $4 \mathrm{~m}$ (throw) $9 \mathrm{~m}$ (horizontal) & Chinshui/Kueichulin \\
Nantou & $035^{\circ}, 25^{\circ} \mathrm{E}$ & $1-2 \mathrm{~m}$ (displacement) & Chinshui/Toukoshan \\
TCDP & & $6 \mathrm{~m}$ (displacement) & Chinshui/Chinshui
\end{tabular}




\subsection{Laboratory Methods}

Optical microscopy from standard thin sections was completed for samples from core and outcrop of the Chelungpu fault. Bulk and clay X-ray Diffraction (XRD) was used to determine sample mineralogy and clay composition and relative amounts for the Chelungpu fault zone. Unoriented (end-packed) hand-powdered bulk samples were analyzed over a range of $5^{\circ}$ to $75^{\circ} 2 \theta$ using copper $\mathrm{K}$-alpha radiation and a $\mathrm{Cu}$ target with voltage $=45 \mathrm{kV}$ and current $=40 \mathrm{~mA}$. Bulk powder samples were used for evaluation of relative amounts of clay in samples (as verified by oriented clay samples). A $1 \mathrm{ml}$ slurry mixture of clay and distilled water was airdried on glass slides. Oriented clay samples were analyzed over a range of $3^{\circ}$ to $33^{\circ} 2 \theta$ (Fig. 2). Ethylene glycol was used to expand the clay samples and test for swelling clays. Heating samples to $550^{\circ} \mathrm{C}$ helped distinguish kaolinite from chlorite, as the structure of kaolinite collapses with heat. Geochemical analyses using X-ray fluorescence (XRF) and Inductively Coupled Plasma (ICP) Mass Spectrometry (MS) $\mathrm{LiBO}_{2}$ fusion analysis were used to detect the percent amounts of major, minor, and trace elements with a detection limit of $0.01 \%$ for major and minor oxides and $10 \mathrm{ppm}$ for trace elements (Fig. 3). Loss on ignition (LOI) of volatiles, primarily $\mathrm{H}_{2} \mathrm{O}$ and $\mathrm{CO}_{2}$, was determined from baking the samples and recording the weight loss.

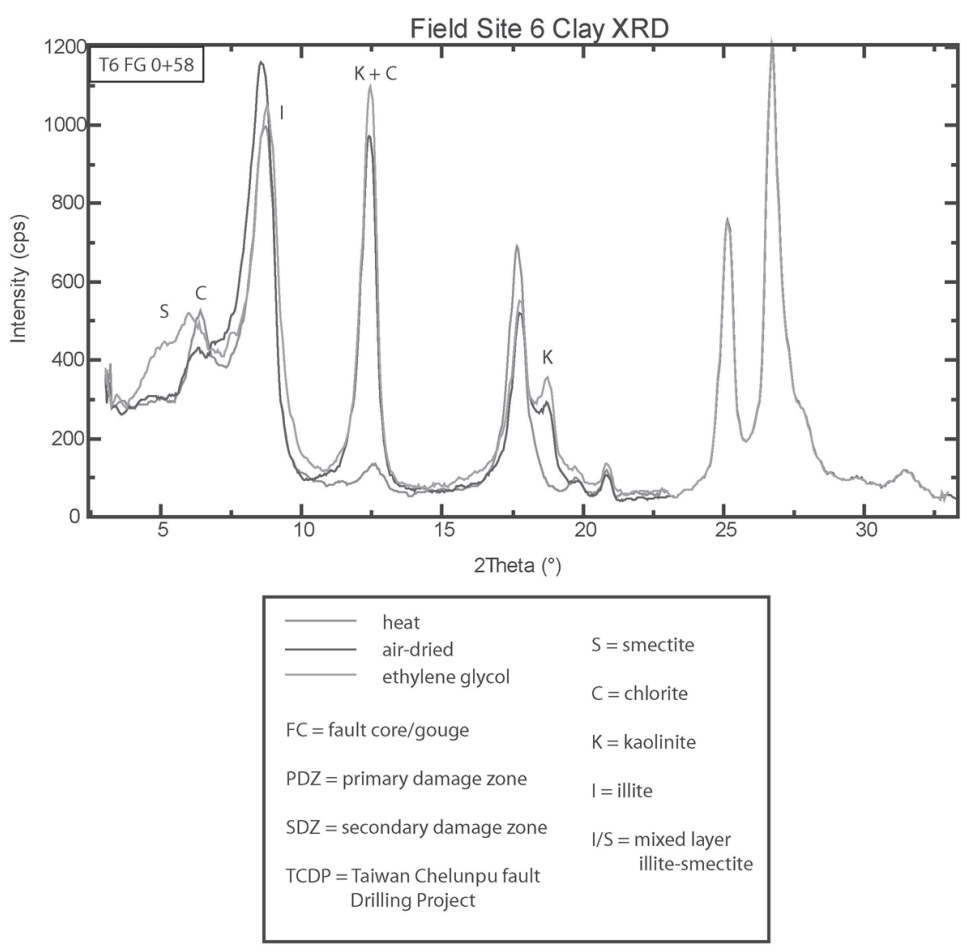

Fig. 2. Example plot of X-Ray Diffraction analysis on clay samples. 

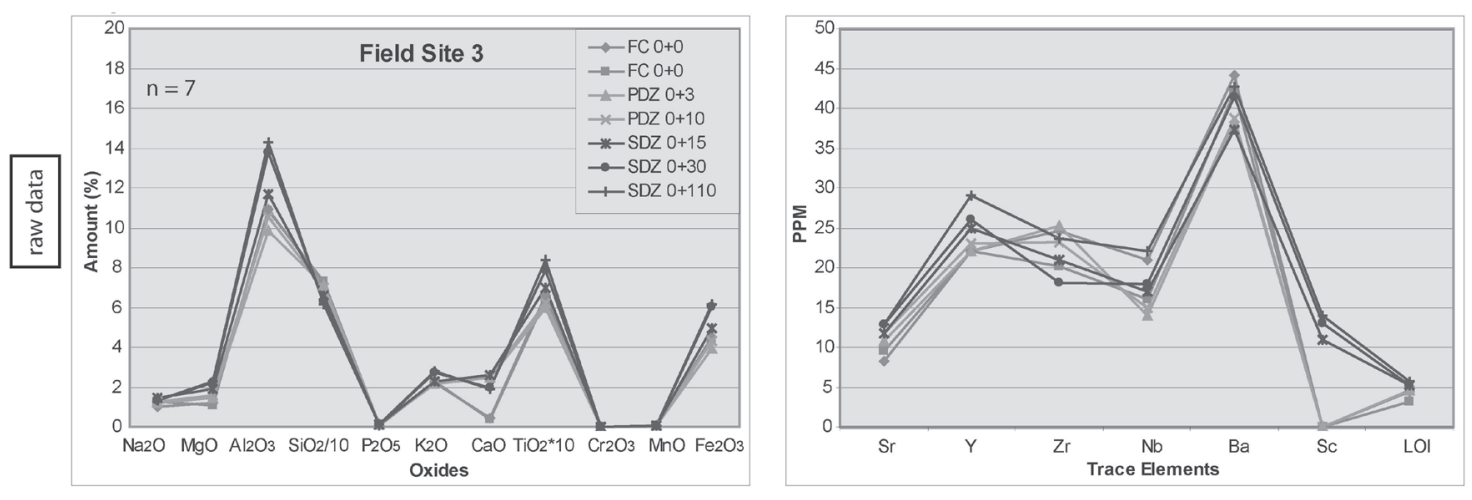

Fig. 3. Example graphs illustrating geochemical results from samples using $\mathrm{X}$-Ray Fluorescence techniques.

\section{CHARACTERIZATION OF CHULUNGPU FAULT ROCKS}

\subsection{Field Site 1: Tachia River (224823 E, 2686232 N)}

The northernmost field site along the trace of the Chelungpu fault is located on the Tachia River where the 1999 rupture created a waterfall and broke the Pifung Bridge (Fig. 4; Chen and Lin 1999). Bedding throughout this outcrop is uniform and strikes $045^{\circ}$ with dips ranging between $34^{\circ}$ and $56^{\circ} \mathrm{SE}$ (Heermance et al. 2003; this study). The primary damage zone is characterized by an increased number and orientations of fractures until $\sim 17 \mathrm{~m}$ into the hanging wall (Fig. 5). No fault gouge is preserved in the outcrop, and the primary slip surface is below the water level, so it is unknown whether gouge was associated with this fault or not. A conjugate fracture set dominates the secondary damage zone with bearings of $\sim 022^{\circ}$ and $\sim 070^{\circ}$. Minor slip has occurred on some of the $022^{\circ}$ joints, and these are more continuous than the $070^{\circ}$ fracture set. There are a few secondary faults that are sub-parallel to the main fault and bedding with very little offset (Fig. 4; Lee et al. 2002; this study).

Thin sections of samples collected from site 1 show intact rock with relatively little damage except a few micro-fractures and no evidence of shear within $1 \mathrm{~m}$ of the fault. There are a few quartz grains with intragranular fractures, but no foliation is developed in very fine-grained clayey layers (PDZ 0+1; Fig. 6a). Pteropod fossils that are originally circular in cross section (Scholle 1978) show no sign of elongation within $1 \mathrm{~m}$ of the fault trace (PDZ 0+1; Fig. 6b). Quartz is the dominant mineral in thin section, with minor amounts of twinned feldspar, pyrite and/or hematite, and lithic fragments. Calcite cement and fine-grained brown matrix are also present. Fine-grained rocks along a secondary fault $\sim 25 \mathrm{~m}$ into the hanging wall are not foliated (SDZ 0+25; Fig. 6c). Occasionally, clay is concentrated in very thin, opaque, dark bands, but there is no evidence that these clays are related to or modified by faulting. 
X-ray diffraction analysis (XRD) identifies quartz, feldspar, calcite, and clay minerals including kaolinite, illite, and chlorite \pm smectite (montmorillonite) in all samples collected at site 1 . The relative abundance of the clay mineral smectite increases towards the fault trace, and kaolinite + chlorite decrease toward the fault (Fig. 7). Clay XRD affirms the presence of smectite in the primary damage zone rocks mixed with chlorite, illite, and kaolinite (PDZ $0+0$, PDZ 0+1, PDZ 0+10). Mixed layer illite-smectite (I-S) is likely present in a sample collected $1 \mathrm{~m}$ from the main fault (PDZ 0+1) identified by decreased peak intensity at $\sim 6^{\circ} 2 \theta, 8^{\circ} 2 \theta$ and $17.7^{\circ} 2 \theta$ upon glycolation, and a peak shift from $\sim 8^{\circ} 2 \theta$ to slightly higher values of $2 \theta$ (Moore and Reynolds 1997). There is also the possibility of a peak at $\sim 3.4^{\circ} 2 \theta$ in sample PDZ $0+1$, which indicates R1 (ordered) I-S. Newmod ${ }^{\mathrm{TM}}$ (Reynolds and Reynolds 1996) modeling also indicates the presence of I-S in samples PDZ $0+0$ and PDZ $0+1$ (Fig. 8).

Whole-rock geochemical analysis shows that the oxides $\mathrm{MgO}, \mathrm{Al}_{2} \mathrm{O}_{3}, \mathrm{~K}_{2} \mathrm{O}, \mathrm{CaO}, \mathrm{TiO}_{2}$, and $\mathrm{FeO}_{3}$, trace elements $\mathrm{Sr}, \mathrm{Y}, \mathrm{Nb}, \mathrm{Ba}, \mathrm{Sc}$, and loss on ignition (LOI) of the primary damage zone are depleted relative to the secondary damage zone, whereas $\mathrm{SiO}_{2}, \mathrm{Na}_{2} \mathrm{O}$, and $\mathrm{Zr}$ are enriched in the primary damage zone. The geochemical signature of the primary damage zone is primarily depleted from that of the secondary damage zone.

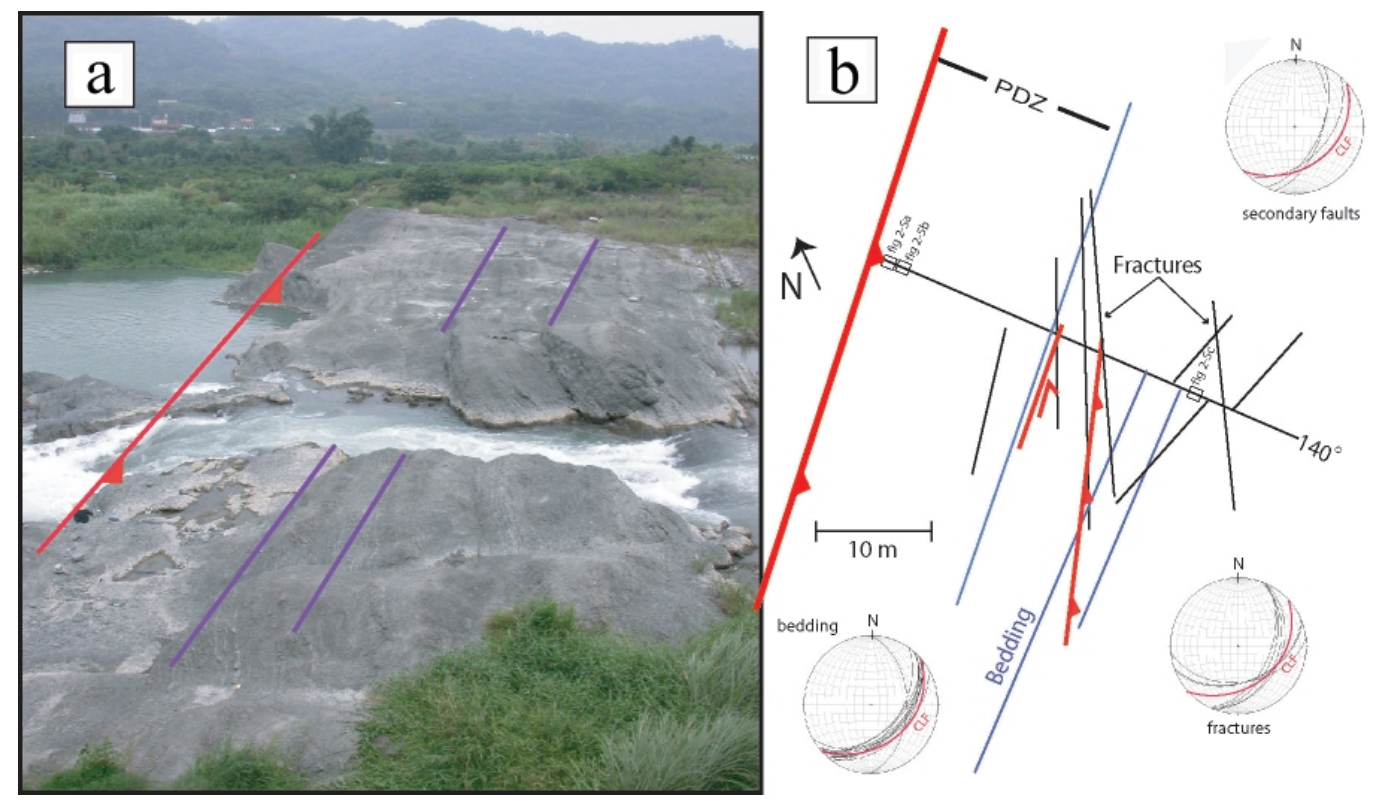

Fig. 4. Field site 1. a) View to the north of the Tachia waterfall created in the 1999 rupture of the Chelungpu fault (photo taken in 2004). The red line indicates the trace of the surface rupture, and blue lines indicate bedding. b) Transect of site 1 (plan view) illustrating the orientation of the 1999 rupture, fractures, bedding, and secondary faults. River flow is to the left (west). 

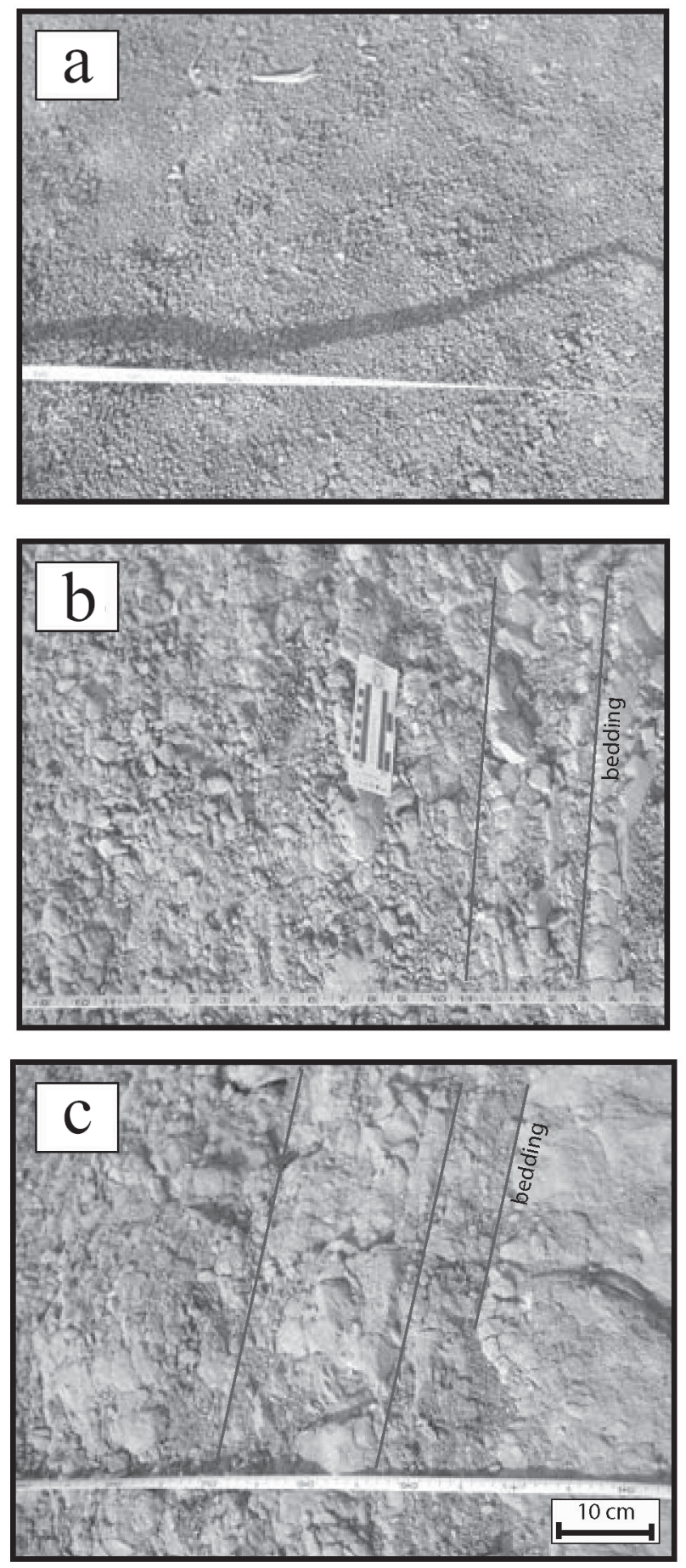

Fig. 5. Examples of the damage zone at field site 1. a) Brecciation zone $\sim 70 \mathrm{~cm}$ from 1999 rupture trace. b) Intact bedding within $3 \mathrm{~m}$ of the 1999 rupture trace. c) Bedding and typical rounded weathering and fracture pattern of the Chinshui Shale at $\sim 32 \mathrm{~m}$ from the 1999 rupture trace. 

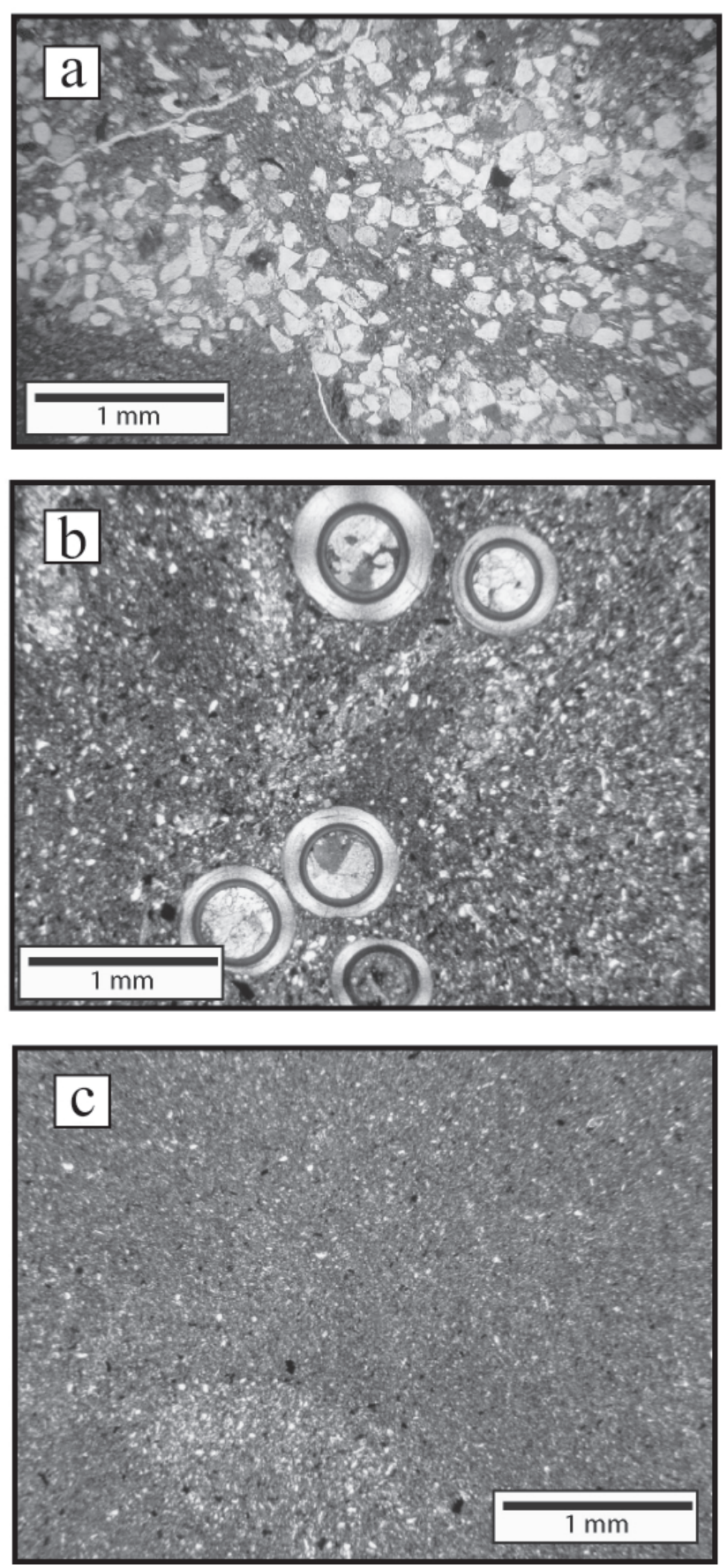

Fig. 6. Photomicrographs of field site 1 samples. a) Photomicrograph showing intact host rock $\sim 1 \mathrm{~m}$ from the 1999 rupture at field site 1 , Tachia River. Some intergranular microfractures are present, but grains are undamaged, and fine-grained layers show no shear fabric (polarized light). b) Crosssections of pteropods show no evidence of shear $\sim 1 \mathrm{~m}$ from the main fault (polarized light). c) Very finegrained layers of shale along a secondary fault show no development of shear fabric $\sim 25 \mathrm{~m}$ into the hanging wall (polarized light). 

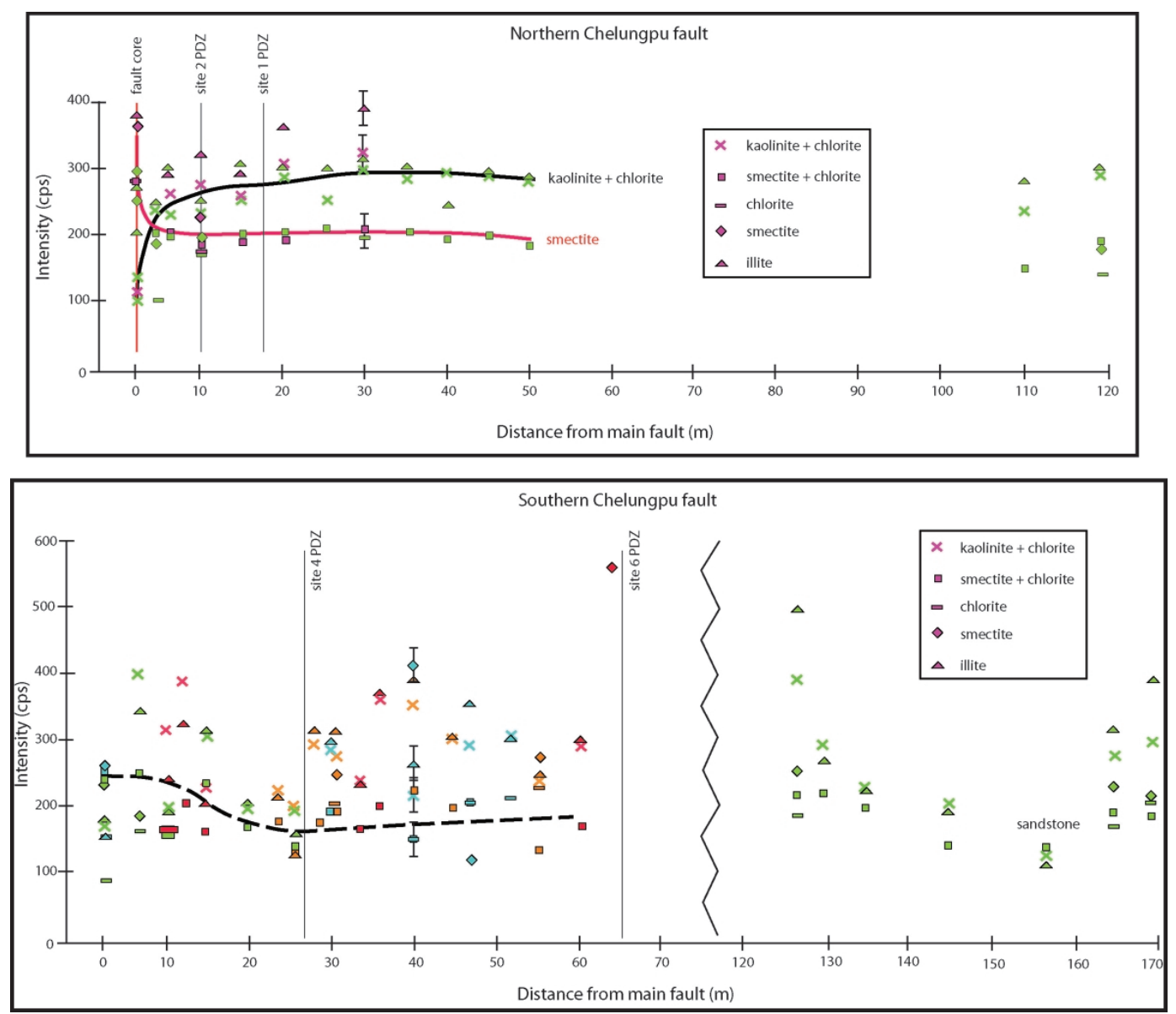

Fig. 7. Plot of peak intensities from XRD patterns for major clay constituents of the northern Chelunpgu fault rocks. Peak intensity is a function of the amount of the mineral present in a sample, and can therefore be used as a proxy for relative abundance. Each clay type can only be compared to itself, not other types of clay using this method. Northern Chelungpu fault: purple symbols $=$ field site 1 samples, green symbols $=$ field site 2 . Smecite is most abundant in the fault core and primary damage zone rocks, and kaolinite + chlorite and possibly illite (field site 3 ) are least abundant in the fault core. Southern Chelungpu fault: blue symbols = field site 4 fault gouge, green symbols = field site 4 damage zone, red symbols $=$ field site 6 fault gouge, orange symbols $=$ field site 6 damage zone. There is not an easily distinguishable pattern of clay mineral abundances, however smectite may be most abundant in the fault core and other fault gouge. Error bars $=+/-2$ standard deviations. 

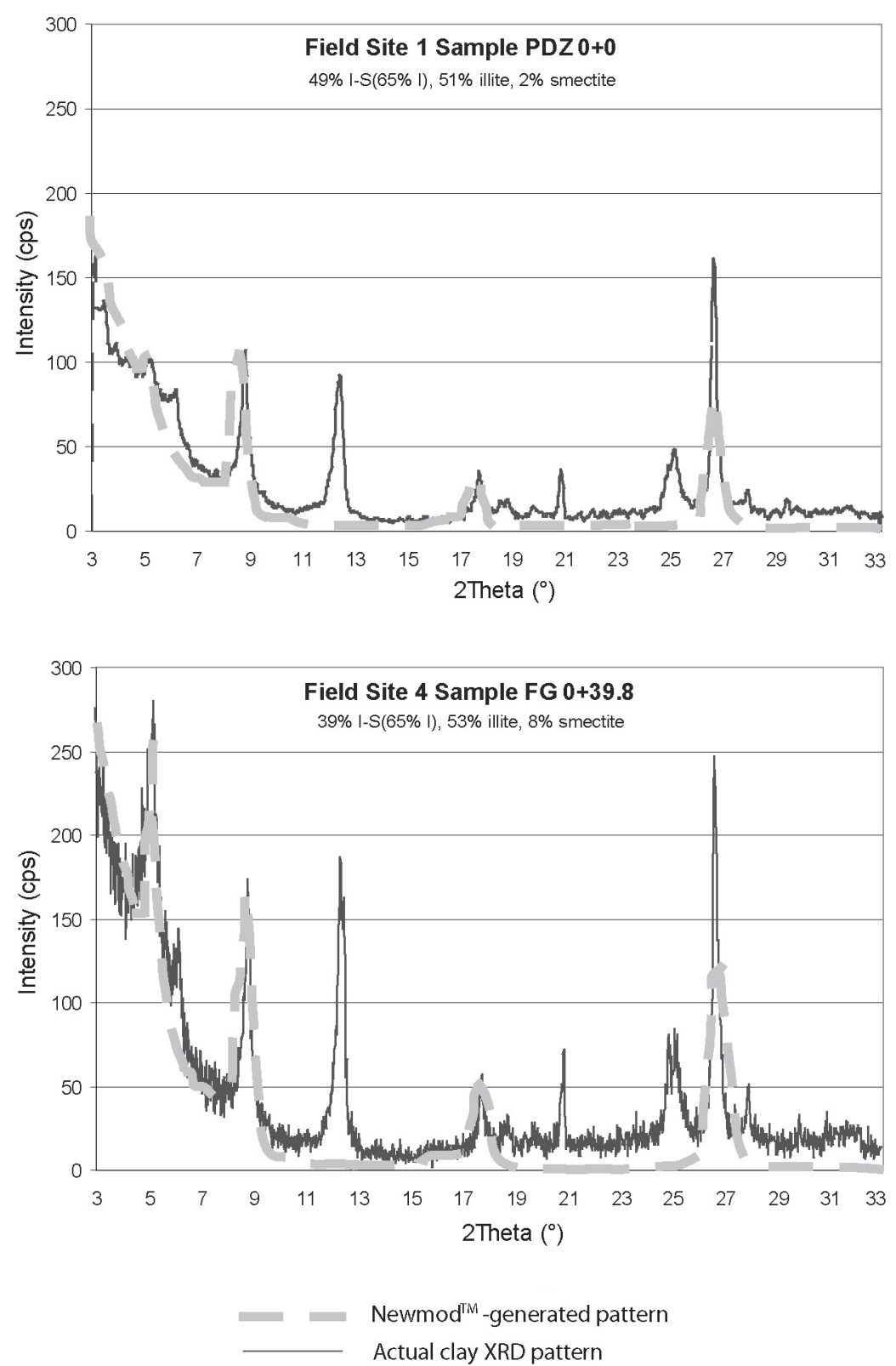

Fig. 8. Examples of NEWMOD ${ }^{\mathrm{TM}}$-generated patterns for I-S, illite, and smectite clays. The poor match of the peaks at $\sim 27^{\circ} 2 \theta$ is due to fine-grained quartz present in the Chelungpu fault zone samples, as illite and quartz have a common peak at this position. 


\subsection{Field Site 2: Tali River ( 222105 E, 2674552 N)}

Additional optical microscopy and clay XRD analysis were conducted for samples from Field Site 2 (Fig. 9). Thin sections of the damage zone show little microstructural deformation within $1 \mathrm{~m}$ of the main fault. At $\sim 1 \mathrm{~m}$ into the hanging wall, fine-grained matrix material shows no evidence for shear. A sample collected $\sim 20 \mathrm{~cm}$ above the main fault has a finegrained matrix with very weak foliation, but foraminifera appear undeformed. Clay XRD identifies abundant smectite in the secondary damage zone ( $\sim 50 \mathrm{~m}$ from the fault; Heermance et al. 2003, their Fig. 15) and to a lesser extent in the fault gouge and near-fault primary damage zone rocks (CDR-1 - PDZ 0+0.7, CDR-2 - FC 0+0, CDR-4 - PDZ 0+0.4, CDR-6 - FC 0+0, CDR-8 - FC 0+0; Fig. 7). The clay XRD pattern of the fault core illustrates a shift in the smectite peak, and also a small split upon glycolation (CDR-8 - FC $0+0)$. This indicates that the peak at $\sim 6^{\circ} 2 \theta$ is a result of smectite, mixed with a lesser amount of chlorite or possibly vermiculite. Sample CDR-9 collected $\sim 2 \mathrm{~m}$ into the hanging wall contains the least amount of smectite. Illite, kaolinite, and chlorite or vermiculite are also present in all components of the fault zone (Heermance et al. 2003; this study). Geochemical analysis is not available for this site.

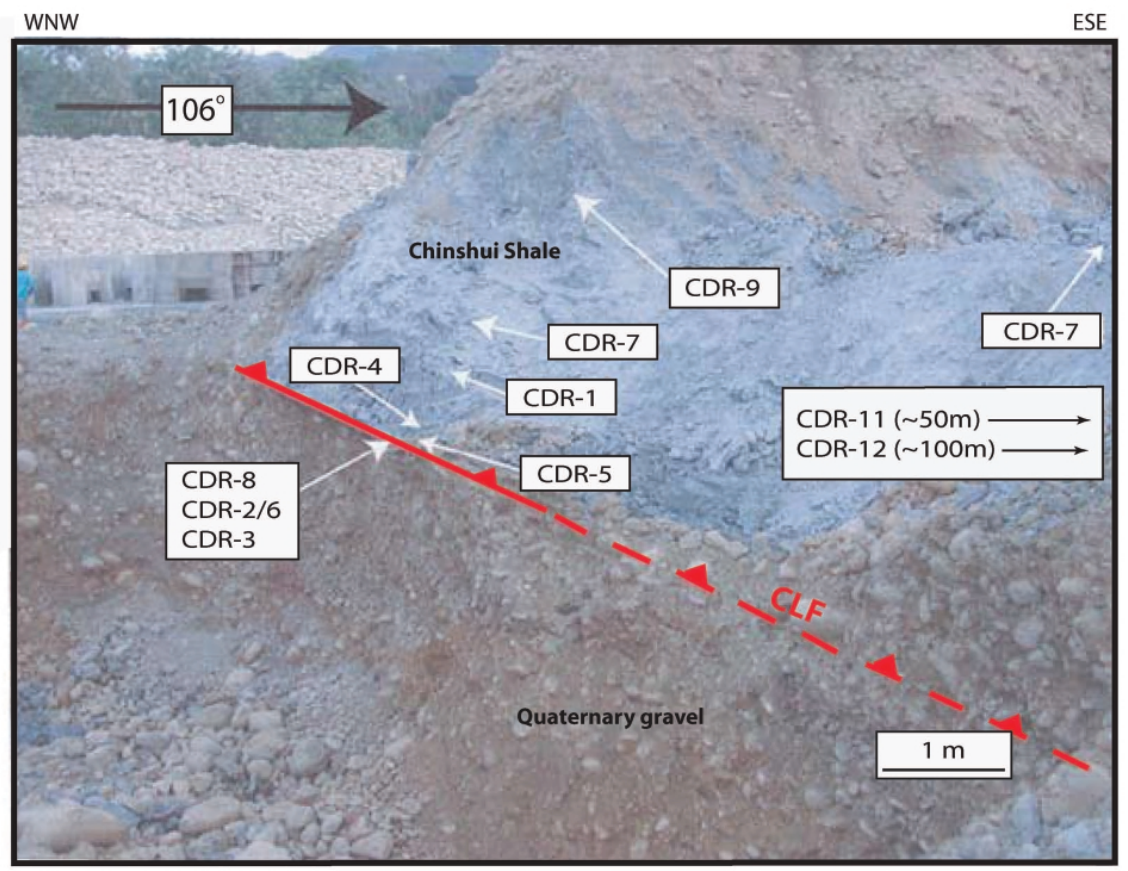

Fig. 9. Photograph of outcrop at field site 2 near the Tali River showing the locations of samples collected and used for thin sections and XRD (Heermance 2002; Heermance et al. 2003; this study). Figure modified from Heermance et al. (2003; Fig. 6). 


\subsection{Field Site 3: Pu Tze River (223036 E, 2672882 N)}

At the Pu Tze River, the Chelungpu fault is transitional from the characteristics of the northern section to the southern section (Fig. 10a). Here, the fault core is $40-60 \mathrm{~cm}$ thick with several bands of $\mathrm{mm}$ to $\mathrm{cm}$ thick black ultracataclasite. The 1999 rupture as seen in the offset river terrace is just downstream of the main fault contact. The primary damage zone is $\sim 10 \mathrm{~m}$ wide and is characterized by increased fractures relative to the secondary damage zone, leached yellow color, and no relict bedding for $1-2 \mathrm{~m}$ into the hanging wall (Fig. 10b). The secondary damage zone, which extends for the remaining $100 \mathrm{~m}$ of the outcrop, is characterized by folded bedding (Fig. 10c), fractures, a few secondary faults, and a weakly developed fault gouge at $\sim 40 \mathrm{~m}$ into the hanging wall. Secondary faults in this outcrop truncate folds and therefore have accommodated more movement than secondary faults at field site 1, but have little or no increase in damage surrounding them and have no associated fault gouge, and therefore are presumably small and relatively small offset structures.

Thin sections of samples collected from the main fault and wall rock show a coarse fault gouge with thin, dark, ultracataclasite ribbons surrounded by intact wall rock (FC $0+0$; Fig. 11). A thin zone $(<0.5 \mathrm{~mm})$ of broken grains forms a transition between the gouge and primary damage zone rocks. The primary damage zone is fractured with zones of broken quartz grains, but also contains areas of predominantly pristine quartz grains. Thin sections of the primary damage zone located $\sim 30 \mathrm{~cm}$ into the hanging wall of the fault display open fractures and comminuted grains, bordered again by relatively intact rock. The mineralogy of the fault core and primary damage zone observed in thin section is similar to that of field site 1 , with quartz being the dominant mineral, as well as some calcite and feldspar.

$\mathrm{X}$-ray diffraction analysis identifies quartz as the most abundant mineral for all field site 3 samples, with minor feldspar and calcite. Clays consist of illite, kaolinite, smectite and/or chlorite or vermicullite. Smectite is most abundant in the fault gouge, whereas kaolinite + chlorite and illite increase through the primary damage zone and are most abundant in the secondary damage zone samples (Fig. 7).

$\mathrm{X}$-ray fluorescence and ICP analyses show that, with the exception of $\mathrm{SiO}_{2}, \mathrm{Zr}$, and Sc, oxides and trace elements are depleted in the fault core and primary damage zone with respect to the secondary damage zone rocks. The fault core is enriched in $\mathrm{SiO}_{2}$, and notably depleted in $\mathrm{MgO}, \mathrm{MnO}, \mathrm{CaO}$, and $\mathrm{LOI}$ relative to the primary damage zone.

\subsection{Field Site 4: Wu River (218125 E, 2656546 N)}

Field site 4 along a northern branch of the Wu River belongs to the southern section of the Chelungpu fault. The main fault lies within a gully (Fig. 12; Fig. 13a) and corresponds to damaged buildings, a scarp in the road above, and the presence of clay gouge and altered rocks. The fault gouge is $20-40 \mathrm{~cm}$ of saturated, tacky orange clay in contact with gravel in the footwall and light gray clay in contact with siltstone in the hanging wall. The primary damage zone is characterized by veins and leaching along a dense network of fractures and shear fabric ( $0-5 \mathrm{~m}$; Fig. 13b), no relict bedding, and is approximately $20-25 \mathrm{~m}$ wide. Figure 13a is a stylized sketch of the exposure at field site 4 showing the main features of the outcrop. The 


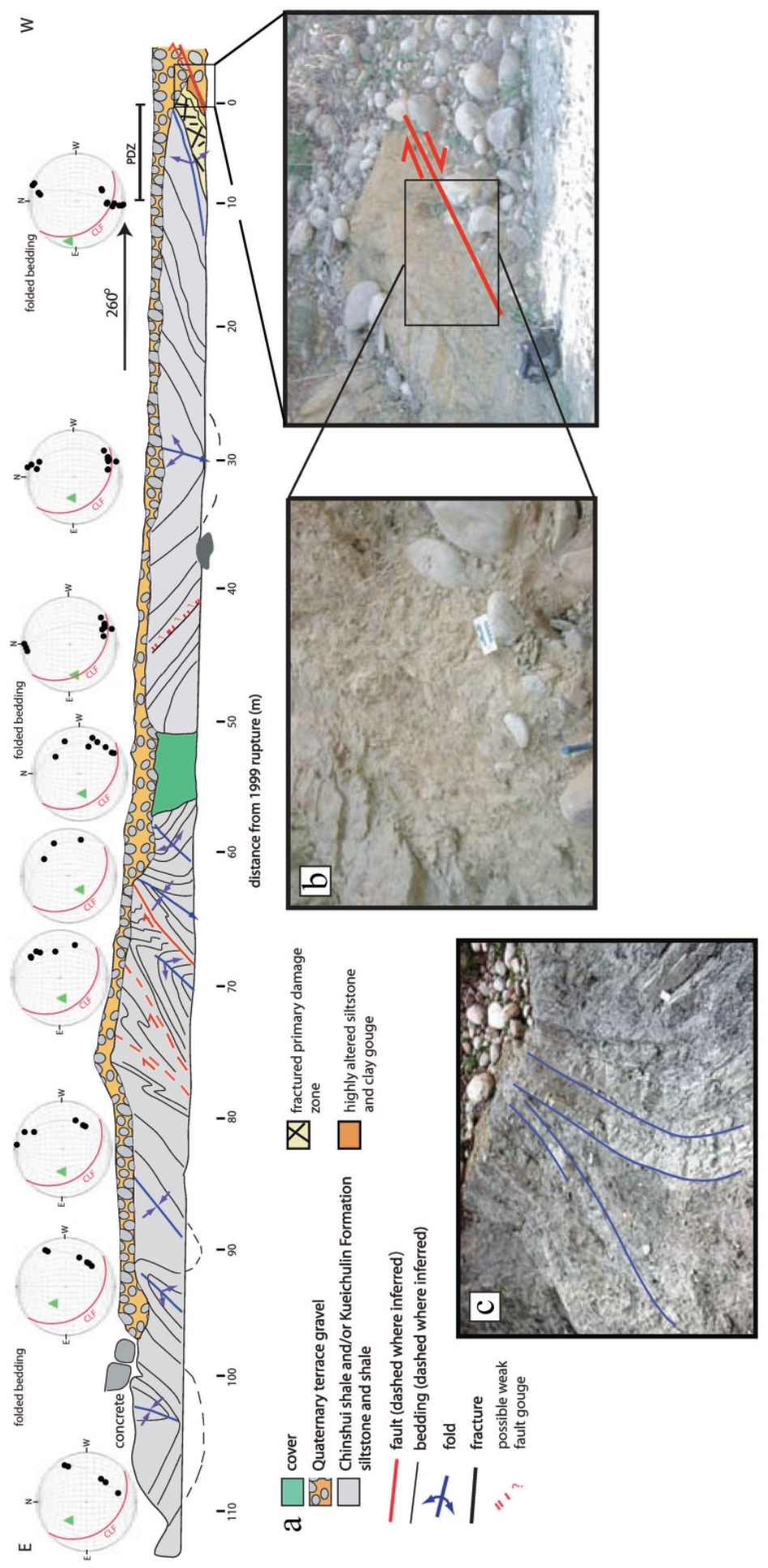

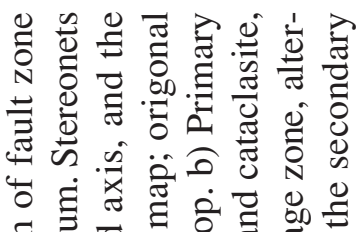

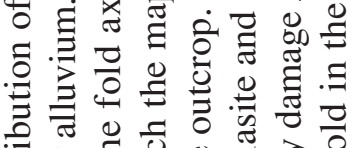

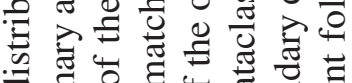

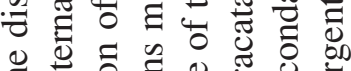

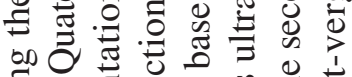

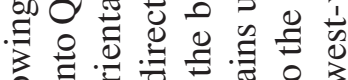

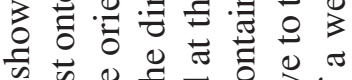
m

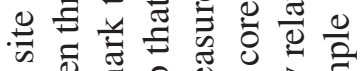

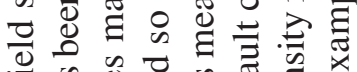

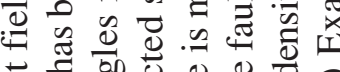
స 은

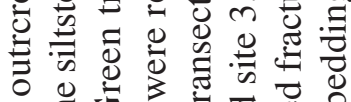

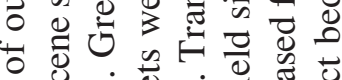

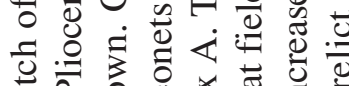
च

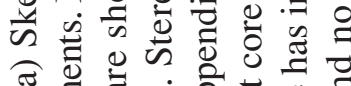
๙

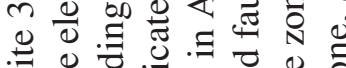
品 8

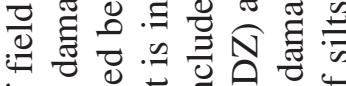

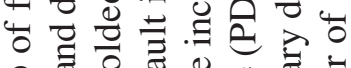

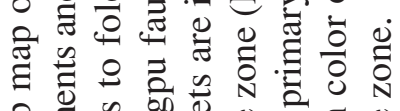
o

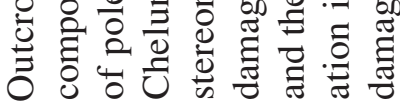
$\stackrel{2}{2}$ $\dot{\infty}$ 


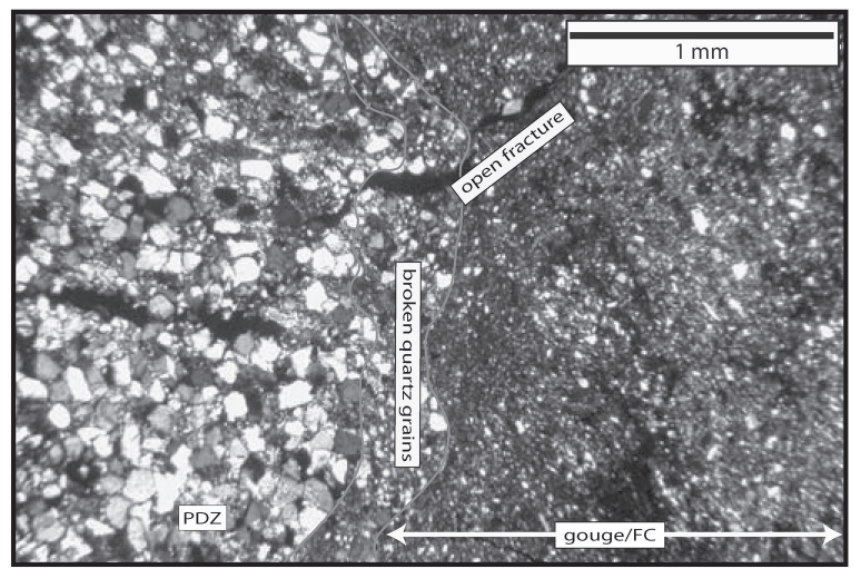

Fig. 11. Photomicrograph of the Chelungpu fault and associated fault gouge collected at field site 3 at $\sim 10 \mathrm{~cm}$ from the contact with Quaternary gravel. Brown fault gouge is on the right, bordered by relatively undeformed primary damage zone (PDZ) rock on the left. The area surrounded by the red line is a transitional area of decreased grain size (polarized light).

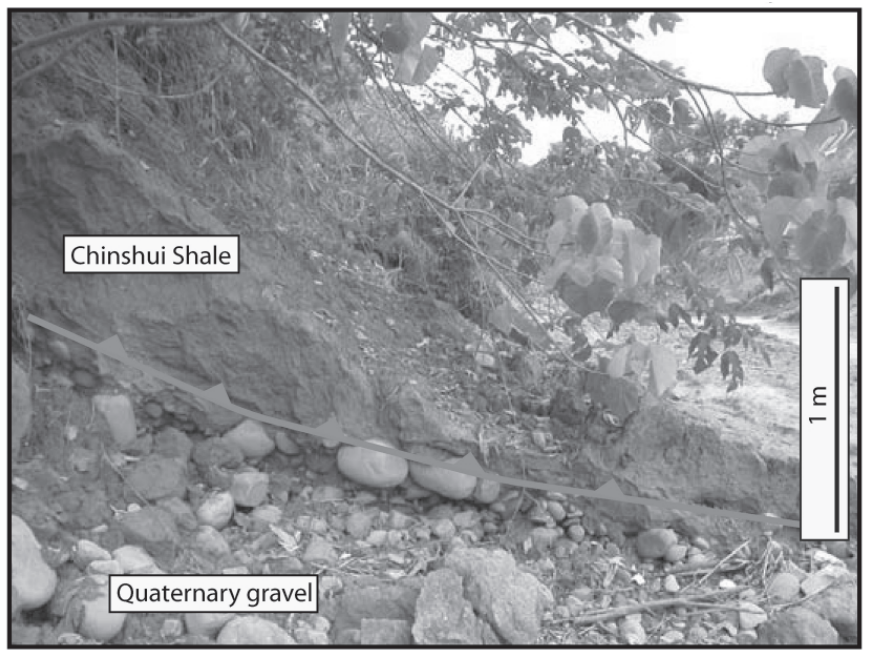

Fig. 12. Field site 4. View to the northwest of the 1999 rupture of the Chelungpu fault. Siltstones of the Chinshui Shale have been thrust onto Quaternary gravel. Although this contact appears suspect in places, it seems to be continous with in-place siltstone down dip, and correlates to damaged buldings and a fault scarp on the road above. 

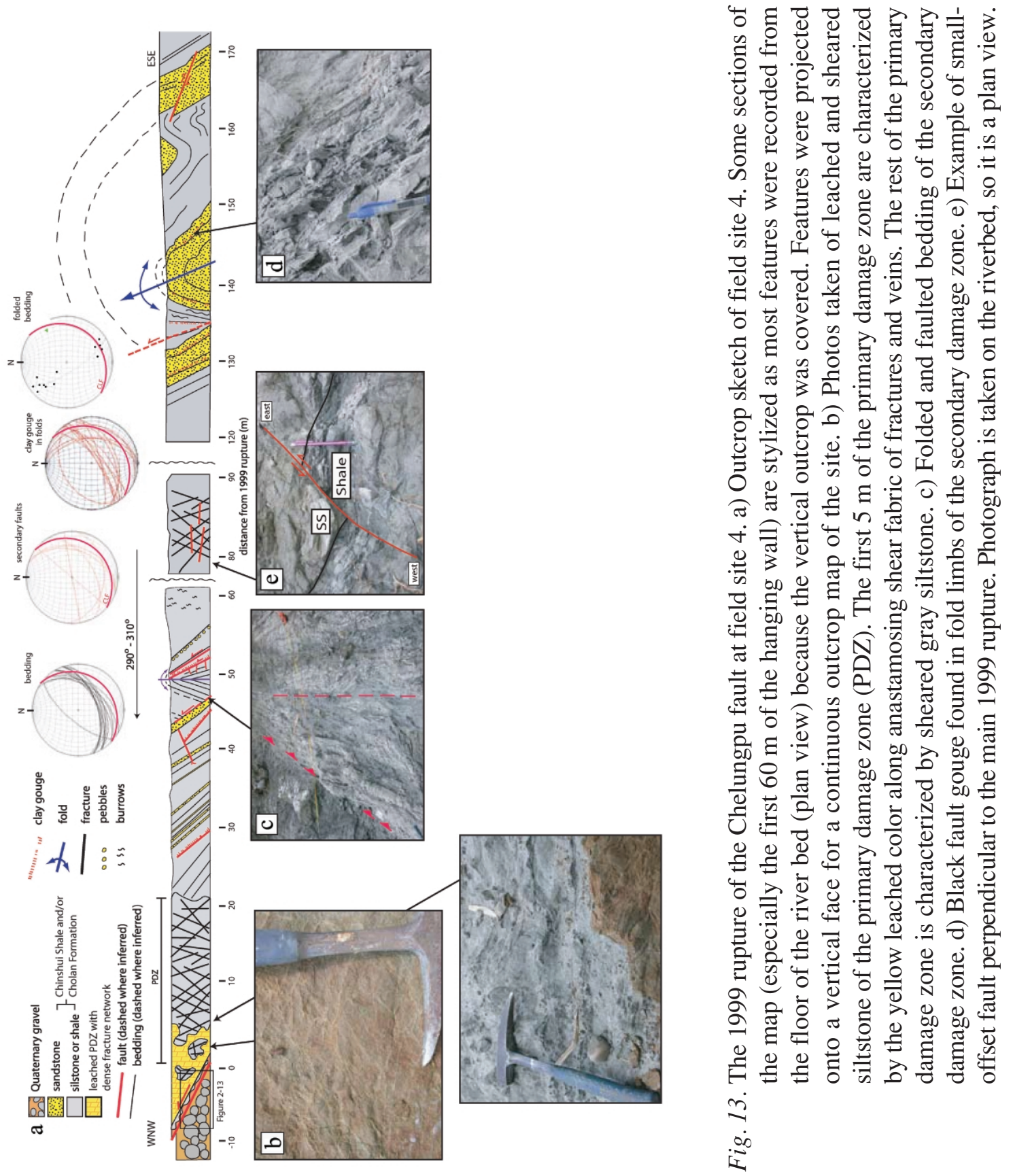
secondary damage zone comprises the remaining outcrop and is characterized by folds that increase in wavelength away from the main fault. Black clay gouge is distributed throughout the secondary damage zone along secondary faults and in fold limbs between sandstone and siltstone beds (Fig. 13a, Fig. 13d). A second 10-m wide major fracture and shear zone is located at $\sim 80 \mathrm{~m}$ into the hanging wall with numerous small offset faults at high angles to the main fault (Fig. 13e). This fracture zone lacks relict bedding in several places.

Quartz is the dominant mineral in thin section. Thin sections display foliated fault gouge $($ FG $0+30)$ and massive clay (SDZ $0+140)$ that may be primary clay or may be gouge overprinted by weathering and subsequent mineral precipitation. Transitions between gouge and host rock are abrupt. Evidence for multiple deformation events include displaced and rotated porphyroclasts of gouge and quartz-rich wall rock $(\mathrm{FG} 0+30)$, multiple generations of foliated gouge at differing orientations that are either truncated by micro faults, or younger bands of fault gouge (FG 0+30, FG 0+148; Fig. 14). Fine-grained, thin shear bands contain comminuted quartz grains that are apparently sheared off of the wall of more intact rock (FG $0+46)$. Small-scale bedding and gouge strands are commonly truncated by microfaults. There is some evidence for plastically deformed quartz grains (SDZ 0+140). Again, quartz dominates the mineral phase observed in thin section, but some grains of chlorite, calcite, and feldspar are also present.

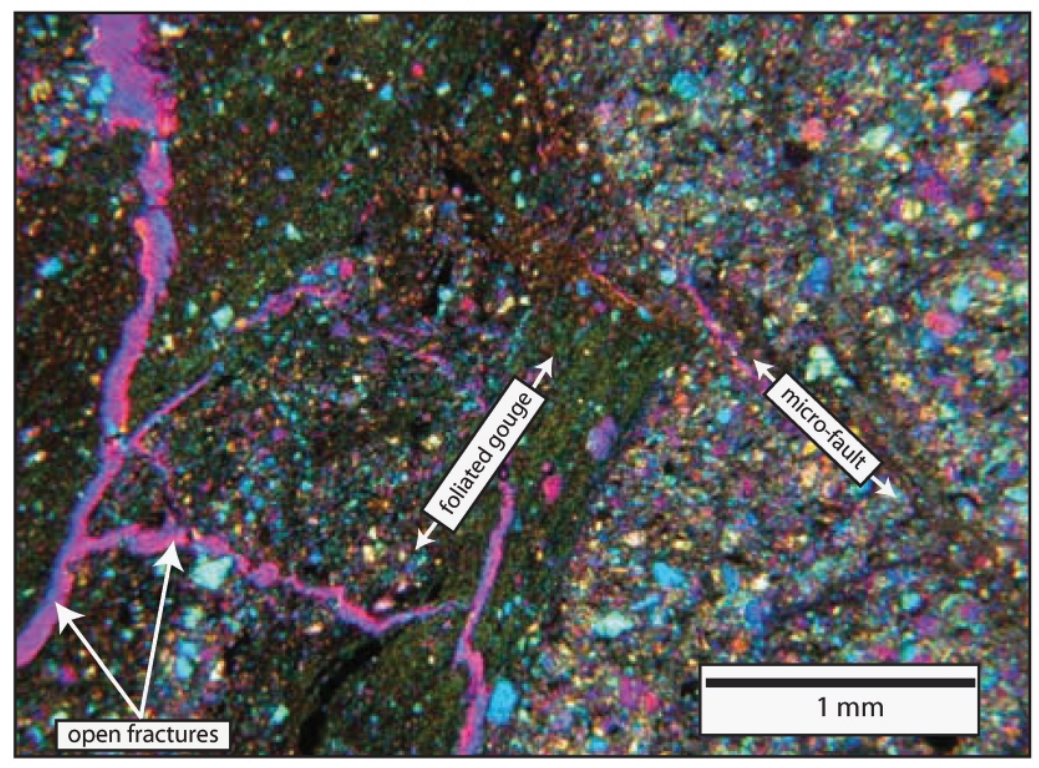

Fig. 14. Photomicrograph of fault gouge sample from field site 4 (FG $0+30)$. Microstructures show evidence for multiple deformation events including multiple generations of foliated gouge at differing orientations that are either truncated by micro-faults or younger bands of fault gouge (polarized light with $530 \mathrm{~nm}$ plate). 
Bulk XRD patterns for samples collected at field site 4 show that the dominant mineral is quartz, with lesser amounts of feldspar, calcite, and clays including kaolinite, illite, chlorite and/or smectite. Within the near-fault primary damage zone, Chlorite/smectite increases towards the fault core, whereas illite roughly decreases towards the main fault. No trend for kaolinite was determined (Fig. 7). Quartz also increases towards the fault core. Clay XRD reveals that smectite is present in the secondary damage zone rocks (SDZ 0+133, SDZ 0+155, SDZ 0+190), as well as in primary damage zone rocks (PDZ 0+0, PDZ 0+5). A significant amount of smectite is present in the primary fault gouge; however; fault gouge in secondary faults range from having significant smectite (FG $0+39.8)$ to being smectite-poor $(\mathrm{FG} 0+53)$. Sample FG 0+39.8 has I-S, illite, and smectite clays (Fig. 8). Secondary fault gouge with variable mineralogy makes the trends in Fig. 7 much more complex.

$\mathrm{X}$-ray fluorescence and ICP results for field site 4 are more complex than those from sites 1 and 3. The ICP values show that fault gouge (FC $0+0$, FG $0+39.8$, FG $0+41$, FG $0+53.2)$ and primary damage zone samples (PDZ $0+0$, PDZ 0+5, PDZ 0+10, PDZ $0+20$ ) are depleted in $\mathrm{MgO}, \mathrm{CaO}, \mathrm{MnO}$, and LOI relative to the secondary damage zone (SDZ 0+170, SDZ 0+185). The fault core is enriched $\mathrm{Al}_{2} \mathrm{O}_{3}$, and the fault core and primary damage zone are enriched in $\mathrm{SiO}_{2}$ relative to the secondary damage zone rocks. In general, and with the exception of $\mathrm{CaO}$, fault gouge is enriched in oxides and trace elements with respect to the primary damage zone, and depleted in oxides relative to the secondary damage zone.

\subsection{Field Site 5: Dong Pu Ruey River (219604 E, 2631775 N)}

Field site 5, part of the southern section of the Chelungpu fault, is an excavation site along the Dong Pu Ruey River. A throw of $1.5 \mathrm{~m}$ was recorded at this site where the uplift dammed the river for a time (Chen and Lin 1999). The outcrop is located completely within the hanging wall of the Chelungpu fault, so only fault gouge from secondary faults was sampled. We infer that the outcrop represents part of the primary damage zone due to the high concentration of slip surfaces, shear bands and clay gouge, and the projected trend of the scarp that dammed the river. Yellow leached bands of siltstone follow fractures and gouge strands throughout the outcrop. The siltstone is also leached yellow at the base of the overlying terrace gravels due to groundwater flow along the contact of the two lithologies.

Quartz is the dominant mineral in thin section, with abundant clay and some feldspar and calcite. Thin sections from field site 5 show several generations of faulting marked by the texture and orientation of different phases of gouge. Brecciated and comminuted quartz grains are common. Gouge is folded and truncated by younger micro faults and strands of foliated fault gouge, and porphyroclasts show rotation and shear tails (Fig. 15).

Bulk XRD analysis identifies quartz, kaolinite, illite, and smectite/chlorite in secondary fault gouge and primary damage zone rocks. Clay XRD patterns show that smectite is present in most samples, but there is no obvious trend. Illite and kaolinite are major constituents of the fault rocks. The ICP and XRF results yield no definitive trend from fault gouge to primary damage zone rocks. This is most likely due to the difficulty in finding samples within the extent of the outcrop that did not contain shear bands and fault gouge. Only 2 primary damage zone samples were collected, and one of these is sandstone that does not provide a good comparison to the sheared siltstones. 


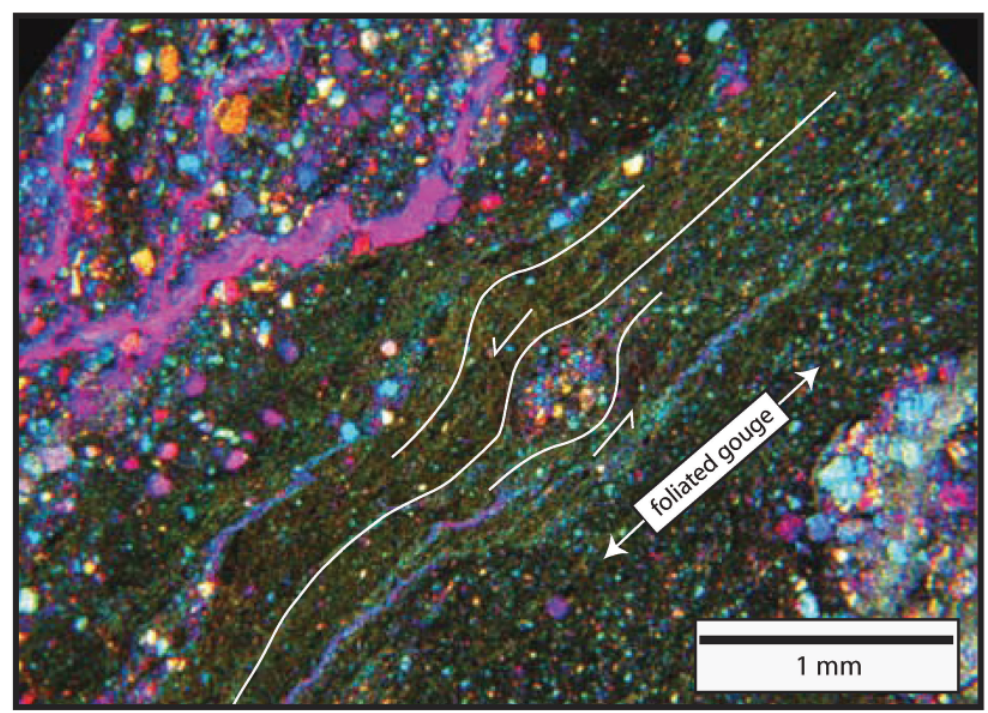

Fig. 15. Photomicrograph of fault gouge from field site 5 (T5-2). Foliated fault gouge, comminuted quartz grains, and microfaults are common microstructures. A rotated porphyroclast of wall rock with associated shear tails is present at the center of the photo (polarized light with $530 \mathrm{~nm}$ plate).

\subsection{Field Site 6: Chin-Sui River (214402 E, 2616438 N)}

Field site 6 is located near the southern terminus of the 1999 rupture trace, and is the final field site of the southern section of the Chelungpu fault. The 1999 rupture broke the Tungtou Bridge. Lin et al. (2005) report that cataclasites and gouge of the main fault are distributed along a 3 - $5 \mathrm{~m}$ wide zone, but determine that coseismic slip was likely localized within a $<50-\mathrm{cm}$ zone. The trace of the 1999 rupture has subsequently been destroyed by construction of a new bridge.

The outcrop is characterized by a very wide primary damage zone $(\sim 65 \mathrm{~m})$ and an extensive secondary damage zone ( $>200 \mathrm{~m}$ ) that is the remainder of the outcrop (Fig. 16a). The primary damage zone is dominated by sheared and foliated siltstone with thin sandstone beds. It has innumerable secondary faults and anastomosing gouge, all of which are very steeply dipping. The gouge is black, extremely tacky, and is often located at contacts between siltstone or mudstone and fine-grained graywacke. One particularly interesting fault gouge is located at $\sim 64 \mathrm{~m}$ into the hanging wall (Fig. 16b). The gouge is $\sim 20 \mathrm{~cm}$ thick, and black with a gold-green luster not observed in other gouges. Curved slicken lines were present on at least one fault plane at $\sim 41 \mathrm{~m}$ from the main fault. Slicken lines were observed on fault planes in very fragile clay films at $\sim 41$ and $55 \mathrm{~m}$ from the main fault (Fig. 16c), suggesting that many 
Isaacs et al.

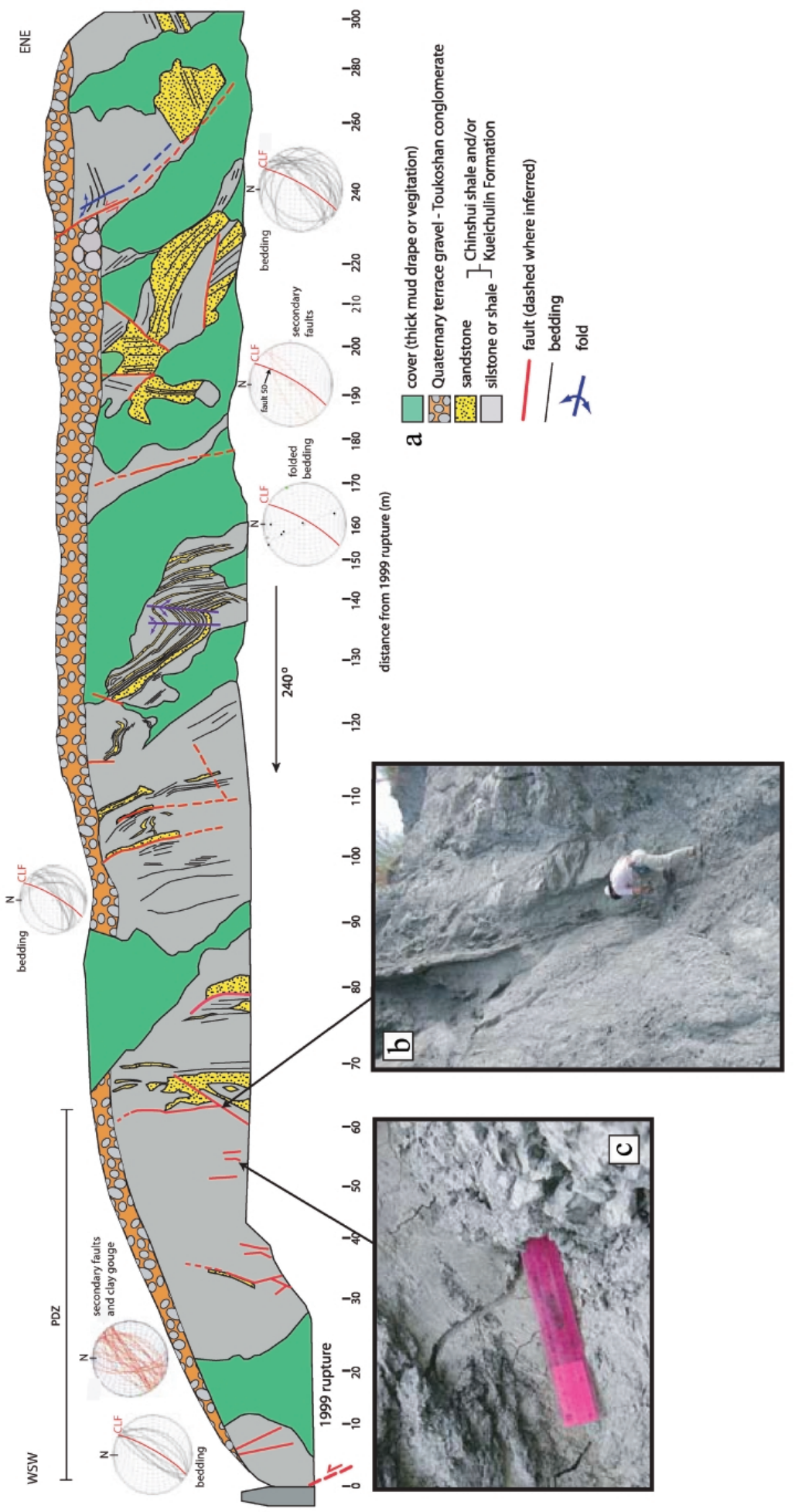

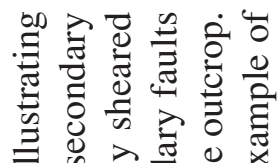

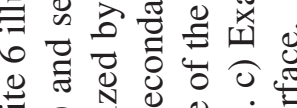

.

ी

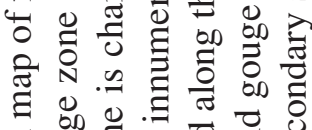

ల్

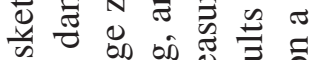

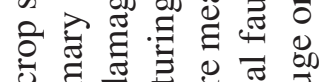

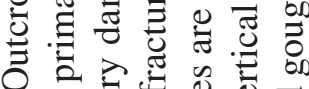

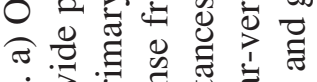

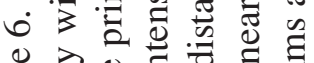

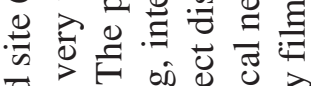

च

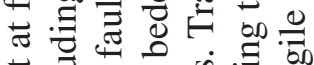

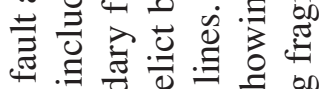

च.

on 0000

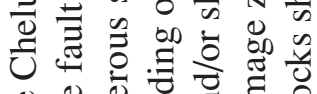

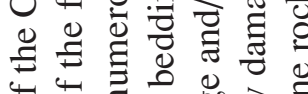

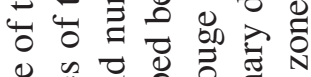

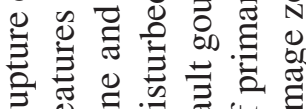

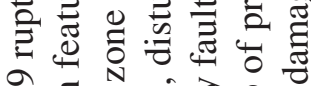

。ิ

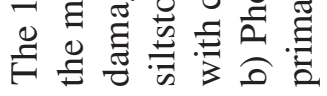

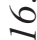

$\dot{0}$ 
surfaces were activated in the recent rupture, as these slicken lines could not be long-lived in this tropical setting. Other features of the primary damage zone include siltstone and sandstone fault breccia zones located at 4 - 9 and $31 \mathrm{~m}$ along the line of transect, intense fracturing, and disrupted and discontinuous bedding. Relict bedding can, in some places, be defined by strands of gouge separating siltstone from sandstone, but these contacts are very irregular, disrupted, and difficult to trace. In many areas of the primary damage zone, where shear fabric and fault gouge dominates, there is no relict bedding.

Within the secondary damage zone, bedding is apparent, however still disrupted, and commonly folded. Numerous secondary faults are present, however there is less fault gouge present in the secondary damage zone than in the primary damage zone. There are several significant faults in the secondary damage zone, including a fault $\sim 250 \mathrm{~m}$ into the hanging wall (fault 50) that offsets Quaternary terrace gravels capping the outcrop. Large round boulders are present in the footwall of this fault that are not present in the hanging wall (Heermance et al. 2003; this study). There is also a $\sim 3 \mathrm{~m}$ high scarp at the surface. Fault gouge associated with this fault is $20-30 \mathrm{~cm}$ thick, contains brecciated clasts, and is foliated, zoned, and well developed. This evidence indicates that there has probably been a significant amount of offset on this fault (Heermance et al. 2003; this study). We do not know if this fault was activated in the 1999 rupture.

Thin sections of fault gouge from field site 6 show the fault core consists of very finegrained material with well developed foliation and a high intensity of deformation microstructures (FG 0+40, FG 0+64, FG 0+240; Fig. 17). Multiple deformation events are clearly recorded by cross-cutting relationships of veins, multiple generations of foliated fault gouge, fractures, and microfaults (FG 0+64, FG 0+40; Figs. 17a, b). Many fractures are simply due to the drying of clays, but some fractures are filled with microbreccia or vein fill (FG $0+64)$. Small, broken, floating quartz grains or pockets of wall rock are incorporated into gouge (FG $0+45 / 112-7$, FG $0+240$ ), and primary damage zone rocks that border gouge have fairly intact quartz grains, but show evidence for increased porosity and deformed matrix (FG $0+30$, FG 0+240; Fig. 17c). Foliated fault gouge with shear fabric is common and well-defined (FG 0+40, FG 0+64, FG 0+41.5, FG 0+58, FG 0+45/112-7, FG 0+10; Fig. 17d). Microfaults that offset foliated fault gouge are filled with calcite, and imply syn-tectonic fluid flow (FG 0+64).

$\mathrm{X}$-ray diffraction analysis identifies quartz, feldspar, calcite, and clay minerals including kaolinite, illite, chlorite, and smectite in most samples collected at this site. Clay is more abundant in fault gouge samples than in surrounding siltstone samples of the primary damage zone (Fig. 7). Samples from the odd lustrous gouge (FG 0+64) are almost entirely montmorillonite. Samples from the primary damage zone and other clay gouge zones are composed of a mixture of chlorite, smectite, illite, and kaolinite (FG 0+10, FG 0+40, FG 0+41.5, FG 0+58, FG 0+64, FG 0+250, PDZ 0+31, PDZ 0+55). Illite and kaolinite are major constituents of secondary fault gouge, and again we find that smectite is present in some secondary fault gouge samples, (FG $0+58, \mathrm{FG} 0+64, \mathrm{FG} 0+250$ ) and is barely detectable or absent in other gouge samples (FG $0+10$, FG $0+40$, FG $0+41.5$ ). Primary damage zone samples contain a significant amount of smectite, illite, and kaolinite, as well as some chlorite (PDZ 0+31, PDZ 0+55). 

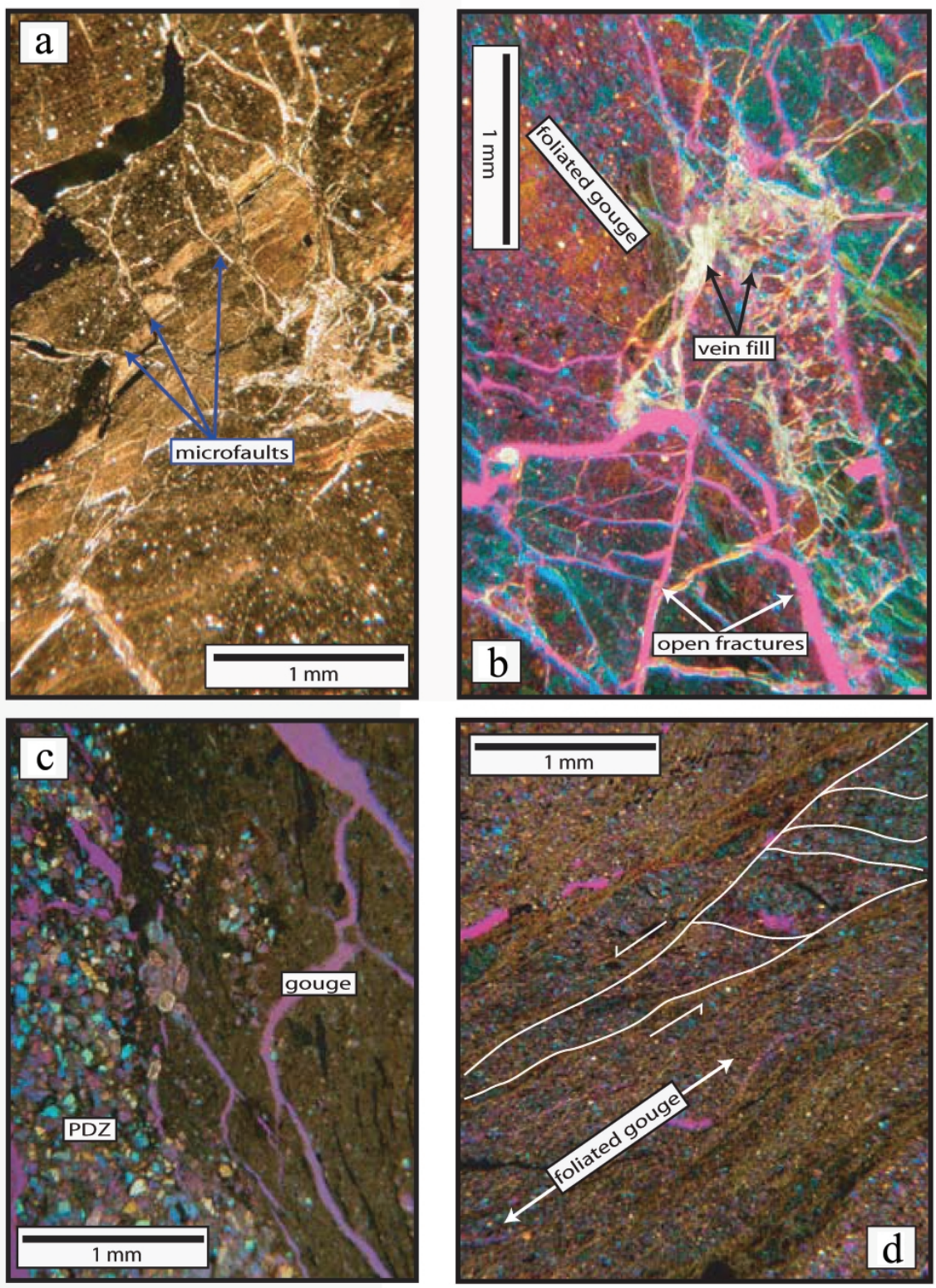

Fig. 17. Photomicrographs of field site 6 samples clearly demonstrate multiple deformation events based on cross-cutting relationships. a) Foliated fault gouge (FG $0+64)$. b) Microfaults filled with calcite offset foliated clay gouge - evidence for multiple deformation events and syn-tectonic fluid flow (FG 0+64). c) More massive fault gouge in contact with primary damage zone (FG 0+10). d) Fault gouge with well defined foliation $($ FG $0+40) . a$ = plain light; $b, c, d=$ polarized light with $530 \mathrm{~nm}$ plate. 
Although samples from this site are compositionally complex, XRF and ICP values indicate that the percent amounts of oxides and trace elements are less in fault gouge (FG $0+10$, FG $0+33$, FG $0+64$, FG $0+250$ ) than in the primary damage zone (PDZ $0+21$, PDZ $0+27$, PDZ 0+40, PDZ 0+55), with the exception of $\mathrm{SiO}_{2}$ and $\mathrm{Zr}$, which are enriched with respect to the primary damage zone. The lustrous gouge sample $(\mathrm{FG} 0+64)$ has a unique geochemical signature that includes a very low $\mathrm{K}_{2} \mathrm{O}$, consistent with the XRD determination that this sample is rich in smectite. In addition, it has the highest value for LOI probably due to interlayer water trapped in the smectite. Sample FC 0+64 follows the trends of other secondary fault gouge samples for $\mathrm{Al}_{2} \mathrm{O}_{3}, \mathrm{CaO}, \mathrm{TiO}_{2}, \mathrm{Y}$, and $\mathrm{Zr}$.

\subsection{Taiwan Chelungpu-Fault Drilling Project (TCDP): Taichung}

For this study, two host rock samples were collected from each of the formations in the TCDP drill hole. The Cholan Formation was sampled at 512 and $796 \mathrm{~m}$ depth, the Chinshui Shale at 1016.5 and 1030.9 m depth (Fig. 18a), and Kueichulin Formation at $1300 \mathrm{~m}$ (Fig. 18b) and $1304.7 \mathrm{~m}$ depth (Song et al. 2007). Quartz is the dominant mineral in thin section. Bulk XRD analysis identifies quartz, feldspar, calcite, and smectite, illite, kaolinite, and chlorite clays. Smectite is a dominant clay in protolith samples. These samples, especially those from the Chinshui Shale and Kueichulin Formation, are used to determine the geochemical alteration of exhumed Chelungpu fault zone rocks. They provide the initial composition of unweathered Chinshui Shale and Kueichulin Formation rocks.

\section{MINERALOGICAL AND GEOCHEMICAL ANALYSES}

\subsection{Geochemical Changes in Fault Zone Rocks}

The geochemical alteration of fault rocks at field sites 1, 3, 4, and 6 were determined using the values of oxides in Chinshui and Kueichulin host rock samples from the TCDP core (TCDP 1030 and 1300) and averaged values of Fengyuan and TCDP host rock as a reference (Fig. 19). Geochemical studies indicate that Ti, Mn, P, and to a lesser extent $\mathrm{Mg}$ are immobile elements (Goddard and Evans 1995; references therein). Using the method described by Goddard and Evans (1995), we determine the percent changes of exhumed fault rocks from host rock. The value of $\mathrm{TiO}_{2}$ was used as the immobile oxide.

The values of $\mathrm{Fe}_{2} \mathrm{O}_{3}, \mathrm{P}_{2} \mathrm{O}_{5}, \mathrm{Cr}_{2} \mathrm{O}_{3}, \mathrm{Al}_{2} \mathrm{O}_{3}$ and $\mathrm{K}_{2} \mathrm{O}$ lie fairly close to the immobile $\mathrm{TiO}_{2}$ axis for all sites. One exception is the pattern of FG $0+64$ at field site 6 ; the lustrous, smectite gouge. The absence of illite accounts for the depletion of $\mathrm{K}_{2} \mathrm{O}$. In addition, the high LOI value is consistent with interlayer water trapped in the smectite, and enrichment of $\mathrm{Fe}$ and $\mathrm{Mg}$ may also be due to an Fe-Mg montmorillonite composition. The Kueichulin Formation (TCDP 1300) is used for the host rock for site 3 based on work by Heermance et al. (2003), and may be host rock for site 6, but using the Chinshui Shale as the reference results in the same pattern. The value of $\mathrm{SiO}_{2}$ is enriched in the fault core and primary damage zone relative to the host rock at each site. With the exception of some damage zone rocks at field site 3 (PDZ 0+3, SDZ 0+15) and sample $\mathrm{FC} 0+64$ from site 6 , the values of $\mathrm{MnO}, \mathrm{CaO}, \mathrm{LOI}$, and often $\mathrm{MgO}$ are notably 


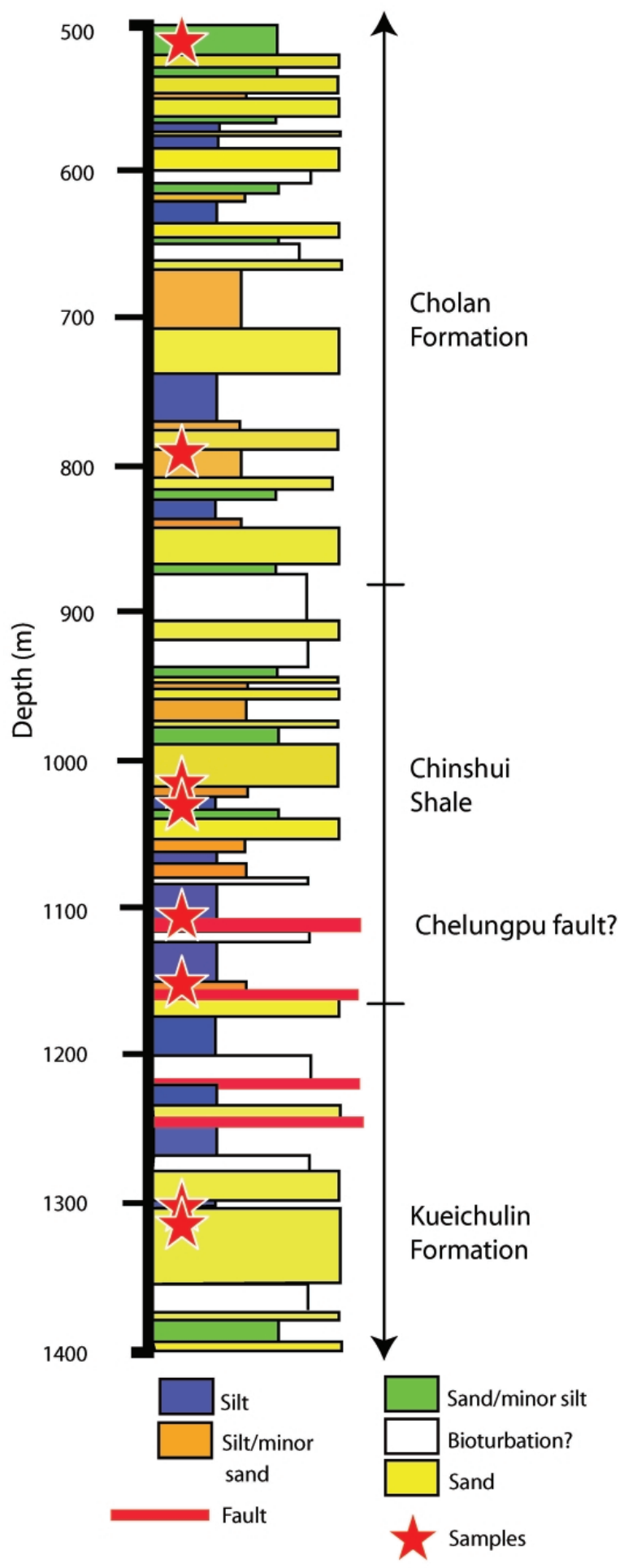

Fig. 18. Generalized lithology of the Taiwan Chelungpu-fault Drilling Project and locations of faults. Formation boundaries are based on nannofossil assemblages (Lin et al. 2007, Wu et al. 2005, 2007). Locations of samples used in this study are indicated by red stars. 
depleted in all components of the fault relative to the host rock, and are increasingly depleted toward the main fault at each site. The extreme depletion of $\mathrm{CaO}(\sim 60-90 \%)$ in fault gouge and primary damage zone rocks indicates the transport of this mobile oxide out of the fault core and surrounding damage zone. The $\mathrm{SiO}_{2}$ enrichment trend indicates transport and precipitation of $\mathrm{SiO}_{2}$ in the fault core and primary damage zone rocks. Fault gouge and damage zone rocks from the Fengyuan and Nantou drilled cores are significantly depleted in $\mathrm{CaO}$, $\mathrm{MnO}, \mathrm{Na}_{2} \mathrm{O}$, and $\mathrm{SiO}_{2}$. The geochemical changes indicate significant fluid-rock interaction. Of the values of $\mathrm{MnO}$ reported for host rocks (Lu 2004; Liao 2003; this study), 4 of 15 samples had high values of $\mathrm{MnO}$; an average of 0.4 percentage points higher than the other 11 host rock samples. This is very significant considering the average of the other samples is $0.07 \pm 0.01 \%$. This variation in the amount of $\mathrm{MnO}$ explains the difference between host rock and fault zone samples shown in Fig. 19.

\subsection{Patterns in Clay Mineralogy}

Some general patterns can be determined from the clay mineralogy of the Chelungpu fault rocks. Figure 7 shows that smectite is most abundant in the fault core and decreases away from the fault in the northern section of the Chelungpu fault. Conversely, kaolinite and chlorite, and possibly illite are least abundant in the fault core and increase away from the main fault. It is much harder to distinguish trends for the southern Chelungpu fault; however, smectite seems to be most abundant in the fault core and in some secondary fault gouge. We have shown that smectite is present in the fault core of the exhumed fault zone and absent or depleted in the fault core at shallow depths. Weathering has been proposed as the agent that forms smectite in exhumed fault gouge (Solum et al. 2003). If, however, weathering is responsible for the smectite, the primary damage zone should presumably be most affected. The primary damage zone is heavily fractured, and likely provides a good conduit for fluid flow. The primary damage zone rocks can be as (if not more) chemically altered as fault core rocks (Fig. 19). Also, the yellow color and vein systems of some primary damage zone rocks at field sites 3,4 , and 5 indicates leaching and fluid flow. The geochemical data suggest that translocation of $\mathrm{SiO}_{2}$ and $\mathrm{CaO}$, and
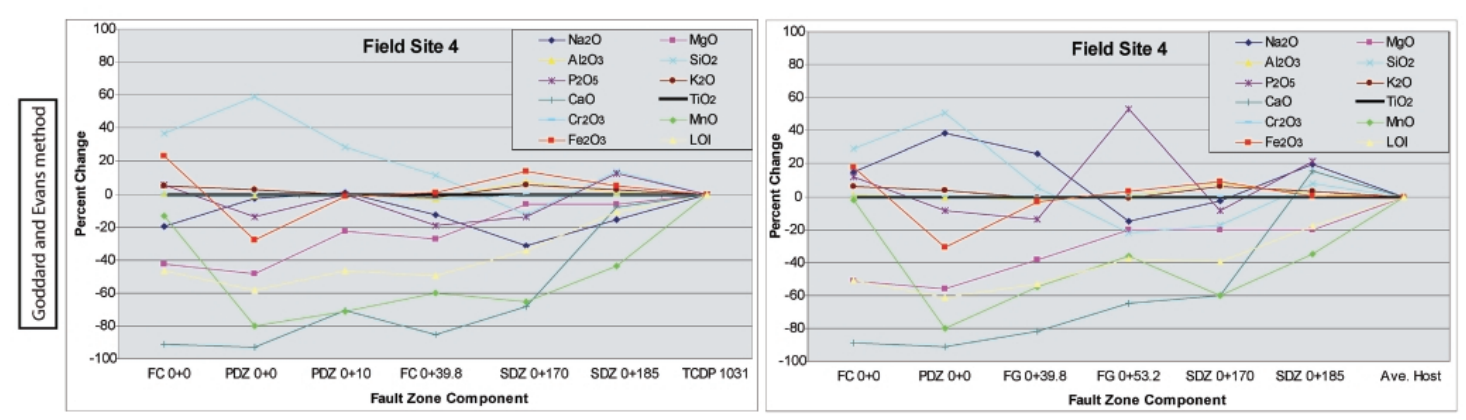

Fig. 19. Geochemical analyses of fault rock samples. 
thus the presence of reaction-driving fluids, is significant in the primary damage zone rocks. Weathering alone does not seem to explain all chemistry and observations of the fault rocks.

\section{DISCUSSION}

The data presented above document the mineralogical, geochemical, textural, and microand macro-scale structural characteristics at 6 sites along-strike and 3 sites down-dip of the Chelungpu fault along $\sim 70 \mathrm{~km}$ of the fault. The meso-scale structures, microstructures, and geochemical signature of the Chelungpu fault zone change along strike, and appear to correlate with variations in fault geometry, ground motion, and total fault displacement. This work allows us to discuss the along-strike and down-dip variations in these aspects of the fault, evaluate fault zone structure, and discuss these results in light of earthquake processes. The variation in the characteristics of the Chelungpu fault at each study site is summarized in Fig. 20.

\subsection{Along-Strike Variations}

Based on the observations of this study, the primary damage zone of the Chelungpu fault is $10-30 \mathrm{~m}$ wide in the northern section and $25-70 \mathrm{~m}$ wide and is more intensely damaged in the southern section. Exposures of the primary damage zone along the northern fault are characterized by increased fracture density relative to the secondary damage zone, whereas the primary damage zone of the southern Chelungpu fault is characterized by intense fracturing as well as the presence of sheared siltstone, abundant fault gouge, and multiple deformation events as recognized by cross-cutting relationships observed in outcrops and thin sections. These differences are mirrored in the Fengyuan and Nantou drill cores. A $7 \mathrm{~mm}$ thick fault gouge is surrounded by a primary damage zone with increased fracture density at Fengyuan, while $1.1 \mathrm{~m}$ of foliated fault gouge is associated with $70 \mathrm{~m}$ of sheared shale in the hanging wall at Nantou (Heermance 2002; Tanaka et al. 2002). Optical microscopy of samples across the northern Chelungpu fault shows relatively undamaged wall rock surrounding coarse fault gouge. Conversely, thin sections of fault zone samples from the southern Chelungpu fault reveal several generations of relatively fine-grained, foliated fault gouge that is folded and truncated by microfaults and veins. Secondary fault gouge with this character is found at some distance from the main fault $(240+\mathrm{m})$. The geochemical data of the northern Chelungpu fault have systematic changes through fault zone components with increasing distance from the fault, whereas the geochemical and mineralogical variations throughout the southern fault zone are more enigmatic with respect to location along the transect line. The complexity of the geochemical signature of the southern fault is in part due to the gouge-bearing secondary faults present throughout the primary damage zone and secondary damage that perturb the geochemical signature relative to distance from the main fault. As a result, geochemistry and mineralogy of the primary damage zone are more variable in the southern Chelungpu fault than the northern Chelungpu fault. Secondary fault gouge of the southern Chelungpu fault can be illite-rich, mixed clays, or smectite-rich.

Lin et al. (2001) report coseismic flexural-slip folding structures sub-parallel to the 1999 rupture of the Chelungpu fault and oriented E-W to NW-SE where there are jogs in the fault. 


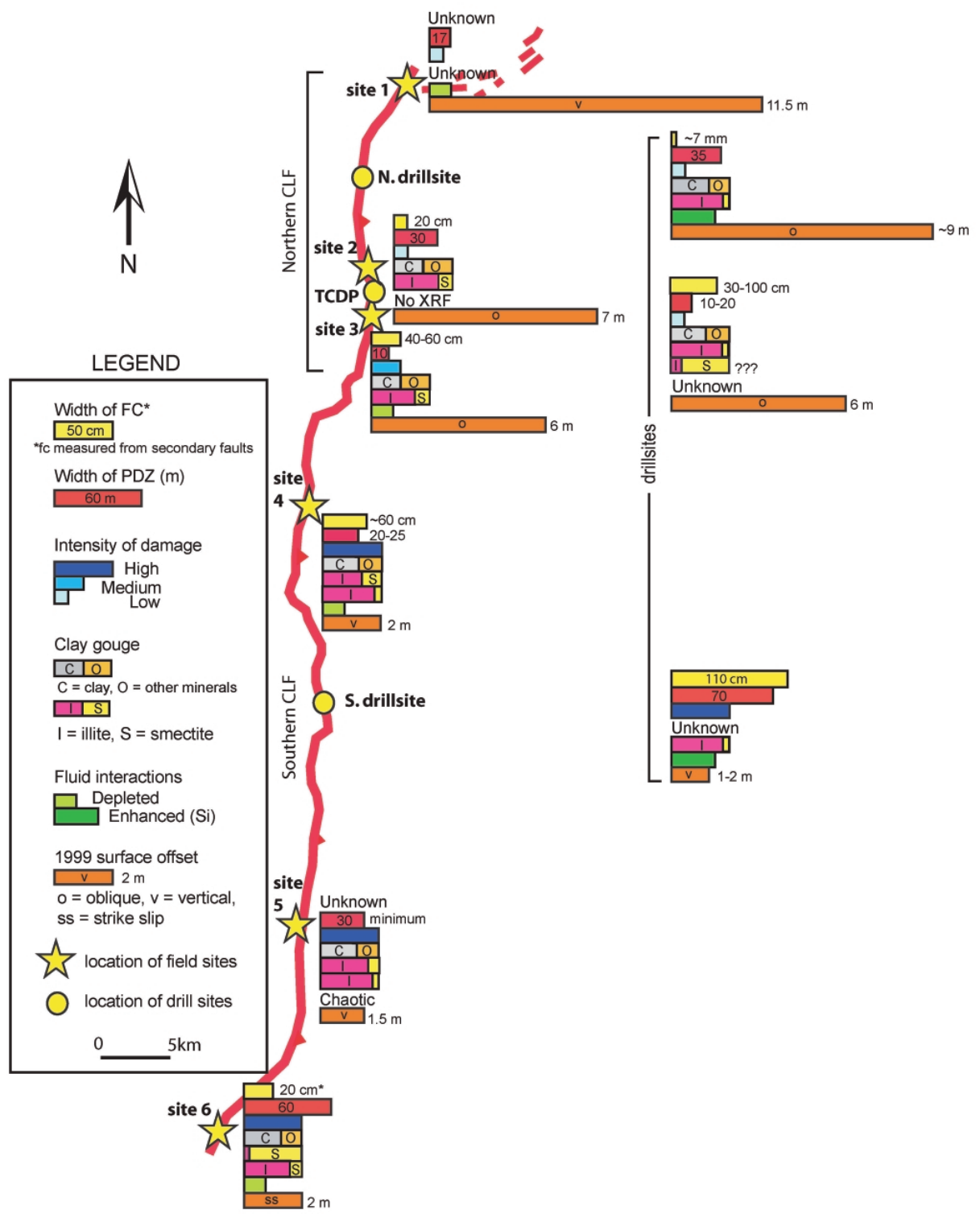

Fig. 20. Differences between study sites showing depth and along-strike variations in offset, fault component size, damage, clay mineralogy, and geochemical signature relative to host rock. The amounts of total clays are qualitative estimates based on optical microscopy of gouge, semiquantitative XRD, and gravity settling. Ratios of illite to smectite are based on NEWMOD ${ }^{\mathrm{TM}}$-generated patterns (Reynolds and Reynolds 1996) and peak intensities. The intensity of damage is a relative measurement based on the type and density of damage recorded in transect of the primary damage zone and secondary damage zone. 
Hanging wall folds are also common at field sites 3 and 4, and fault gouge along folded bedding planes at field site 4 indicates slip. Additionally, the axes of folds at field site 3 and field site 4 trend east-west to northeast-southwest. One model for the Chelungpu fault involves southward-propogating lateral ramps at the extreme northern end of the Chelungpu fault where the fault makes a $90^{\circ}$ turn to the east (Johnson et al. 2001; Johnson and Segall 2004). As the lateral ramps (Sanyi, Houli, and Chelungpu) propagated south, the northern section of the Chelungpu fault also progressively steps to the east into the hanging wall. The Sanyi and Houli faults are projected to converge with the southern section of the Chelungpu fault near Wufeng where the 1999 rupture trace has a right-stepping jog (Fig. 1) and near field sites 3 and 4 . The eastward-propagation of the Chelungpu fault seems to hinge near Wufeng, and may influence the orientations of the complex suite of folds at field sites 3 and 4 . Field site 3 represents a transition between northern and southern sections; indeed we see that field site 3 has more accumulated damage, manifested in folding and ultracataclasites within fault gouge, than sites 1 and 2 .

The northern Chelungpu fault is a relatively new structure in the hanging wall of the old Chelungpu fault/Sanyi fault (Ho and Chen 2000; Heermance 2002) and total displacement along the fault is much less $(500 \mathrm{~m}-1.5 \mathrm{~km}$; Heermance 2002; references therein) than along the southern portion ( $8-15 \mathrm{~km}$; Heermance 2002; references therein). We propose that the intense damage, and complex texture, mineralogy, and geochemistry of the southern Chelungpu fault zone is due to the greater maturity of this section of the fault relative to the northern section. The southern Chelungpu fault has accumulated more damage and alteration, and has numerous secondary faults with fault gouge. The variations in the Chelungpu fault from north to south may illustrate the evolution of a fault through time. Field sites 3 and 4 have complex folding as a result of the transition between the northern and southern Chelungpu fault. The northern segment has been active since at least $\sim 46 \mathrm{ka}$, but does not appear to have been active for more than $\sim 100 \mathrm{ka}$ (Heermance 2002) and illustrates the microstructures and more ordered mineralogy and geochemical signature of a young fault. The southern section, which has $8-15 \mathrm{~km}$ of total displacement, and has been active since $\sim 1 \mathrm{Ma}$ (Hung and Wilschko 1993), provides a comparison to the northern Chelungpu fault and gives insights into the evolution of the Chelungpu fault to its current, more mature state.

Several other factors may influence the along-strike variations in the Chelungpu fault. In the southern section of the Chelungpu fault, siltstones are thrust over the Toukoshan Conglomerate in a hanging wall ramp, whereas in the north, the thrust is bed-parallel and lies within siltstones. The additional frictional resistance due to the conglomerate in the footwall as well as the added stress of the footwall wall ramp geometry may cause the southern section of the Chelungpu fault to have more near-surface damage than the northern Chelungpu fault (Heermance 2002). In addition, the terminus of the 1999 rupture, including field site 6, had a significant strike-slip component.

Along-strike variations in the number and character of slip surfaces, including fluid-rock interactions and mineralogy of fault cores, may influence the rupture style along faults (Evans and Chester 1995), and may play a role in the variable rupture pattern along the Chelungpu fault. Further investigation into the variation of composition, amount, and texture of clay present in fault cores along the Chelungpu fault trace may provide additional insight into the variable 
rupture style of the fault. Co-seismic slip increased northward along the fault trace, however, strong ground motion including high-frequency ground acceleration and fast rupture velocity decreased from south to north (Lin et al. 2001). The wide damage zone and multiple slip surfaces in the southern fault zone indicate that seismic energy is dispersed across a wider zone, and may account for the decrease in slip along this section of the fault (Heermance et al. 2003). Also the more complex and variable composition of fault gouge of secondary faults may play a role in fault rupture. Illite-rich clays in secondary fault gouge may somewhat impede fault propagation to the free surface relative to fault core in the north with a smectite component.

\subsection{Variations with Depth}

Comparison of geochemistry and mineralogy of core samples from the Chelungpu fault zone and host rock at shallow depths indicates that smectite "consumption" takes place locally in fault gouge and to a lesser extent in damaged rock. Smectite is a dominant clay mineral in host rocks of the Chelungpu fault, especially the Chinshui Shale (Kuan 1964), and is partially or completely replaced by illite in fault gouge samples at shallow depths (Liao 2003; Lu 2004).

The drilled core samples examined were not at sufficient depths to drive the smectite to illite reaction by burial temperature alone. The smectite to illite reaction requires temperatures of $100^{\circ}-150^{\circ} \mathrm{C}$ (Freed and Peacor 1989; Hyndman 2004). A simple calculation using a geothermal gradient of $\sim 20^{\circ} \mathrm{C} \mathrm{km}^{-1}$ (Lin 2000) and an average surface temperature of $22^{\circ} \mathrm{C}$ yields a burial temperature of only $\sim 50^{\circ} \mathrm{C}$ for the deepest core samples used in this study (around $1200 \mathrm{~m}$ for damage zone rocks). Temperatures recorded at the base of the Fengyuan and Nantou bore holes were $\sim 28^{\circ} \mathrm{C}$ at $460 \mathrm{~m}$ along the borehole (352.4 $\left.\mathrm{m} \mathrm{TVD}\right)$ and $\sim 25^{\circ} \mathrm{C}$ at $180 \mathrm{~m}$ depth, respectively (Tanaka et al. 2002). These temperatures are well below the temperature requirement for the smectite to illite reaction, despite the findings regarding clay composition by Liao (2003) and Lu (2004).

We propose that seismic energy and fluids may play a role in initiating the smectite-illite reaction at shallow depths in the fault core (Jacobs et al. 2006; Vrolijk and van der Pluijm 1999). Preliminary results from TCDP core show the same mineralogical trends in the footwall as in the hanging wall (L. W. Kuo, pers. comm.; Song et al. 2007), so the illite-rich rocks are probably not a result of simply being carried from depth and greater temperatures. The exhumed fault zone has a mineralogical, and, to some extent $\left(\mathrm{SiO}_{2}\right)$, a geochemical trend that are seemingly reversed from the fault at shallow depths. Smectite is more abundant in the exhumed fault core than in the exhumed damage zone rocks (Fig. 7), whereas smectite is often absent in the fault core at shallow depths. Host rocks from drilled core and exhumed secondary damage zone rocks also commonly have significant amounts of smectite. Primary damage zone samples and fault gouge from secondary faults are rich in illite, and often have the least smectite. These observations indicate that some of the exhumed portions of the fault zone have undergone a retrograde reaction from illite to smectite.

One explanation for the "reversed" mineralogical signature of the exhumed fault zone is that it is due entirely to surficial weathering processes (Solum et al. 2005). However, weathering can not alone account for the geochemical signature. We propose that in addition to 
weathering, the seismic cycle plays an active role in the composition of clay gouge at the surface. If smectite is converted to illite in the fault core by seismic energy as proposed by Vrolijk and van der Pluijm (1999), then one byproduct of the reaction is aqueous silica (Abercrombie et al. 1994). Silica may be translated along the fault during seismic dilatancy (Goddard and Evans 1995) and fault-valve action with dehydration water from the smectite to illite reaction (Moore and Reynolds 1997). Fluids charged with silica accompanied by seismic energy may help to drive a retrograde reaction of illite to smectite by freeing $\mathrm{Al}^{3+}$ and $\mathrm{K}^{+}$and fluxing the system with aqueous $\mathrm{Si}^{4+}$. Chlorite in fault gouge of drilled core samples and microstructural observations of this study indicate the presence of fluids when the smectite to illite reaction occurred (Whitney 1990). Retrograde diagenesis of illite to I-S and smectite in sedimentary rocks induced by hydrothermal fluids has been documented (Zhao et al. 1999; referenced therein). Liao (2003) finds illite-rich gouge in a shallow fault zone at $223.45 \mathrm{~m}$ (171.17 m TVD) in the Fengyuan borehole, and Lu (2004) finds illite-rich gouge as shallow as $123.08 \mathrm{~m}$ depth along the Nantou borehole. The retrograde reaction might be constrained to very shallow depths, or it is possible that the I-S in the fault gouge at shallow depths is a step in the retrograde reaction of I to I-S to smectite. This retrograde reaction may serve to weaken the fault at very shallow depths, and allow the rupture to reach the free surface more easily.

The hypocenter of the September 21, 1999 earthquake was between 7 and $10 \mathrm{~km}$ deep (Ma et al. 2000; Ogelsby and Day 2001), which corresponds to ambient temperatures of 140 $200^{\circ} \mathrm{C}$; this depth has sufficient temperatures to initiate the smectite to illite reaction. Data from other earthquakes in western Taiwan with magnitudes $\geq$ M5 indicate that most seismicity occurs at depths $\geq 5 \mathrm{~km}$ (Shin and Teng 2001). As shown earlier, smectite is absent or reduced in the fault core at much shallower depths $(\sim 200-1000 \mathrm{~m})$ than the seismogenic zone. Hyndman (2004) proposes that the transition from the upper aseismic to lower seismic zone in subduction thrust systems corresponds to temperatures of $\sim 100^{\circ} \mathrm{C}-150^{\circ} \mathrm{C}$, coincident with the initiation temperature of the smectite to illite transition. The upper smectite-bearing portion of the fault core does not radiate seismic energy, but is instead passively "pushed along" (Scholz 2003). Samples used for this study were not from seismogenic depths, but they provide an illustration of the transition from seismic illite and illite-rich I-S to aseismic smectite-rich I-S and smectite. The hypocenter of the 21 September 1999 earthquake was within Hyndman's temperature range for the seismogenic portion of a fault zone.

Our compositional characterization of minerals down-dip along the Chelungpu fault provides useful constraints on the role of mineralogy in fault movement at the near surface. The mineralogy and proposed reactions documented in this study indicate that the smectite-illite reaction may take place up-dip of the seismic-aseismic transition, and may suggest that Hyndman's model is oversimplified. Clay reactions may be driven by fluids and seismic energy all along the fault, and thus the effects of clay on fault weakening are complex. Friction experiments support the idea that illite is seismic and smectite is aseismic (for example, Brace and Byerlee 1966), but the amount of clay needed for this case to be true is unknown (Hyndman 2004; references therein). Quartz is a dominant mineral in fault cores of the shallow Chelungpu fault, and may control the frictional strength of the fault gouge material. If this is the case, clays may help to weaken the frictional strength of the fault, but other factors such as high pore-fluid pressures and dynamic rupture effects (examples in Lockner and Beeler 2002) may 
be needed to completely explain the seismic to upper aseismic transition and weak nature of natural faults.

In addition to the unanswered questions briefly discussed above, the frictional properties of interlayer I-S are unknown. This study indicates that there are significant variations in clay mineralogy down-dip along the Chelungpu fault, and these changes probably culminate in significant smectite to illite reactions at seismogenic depths. Results of frictional tests conducted on montmorillonite and illite indicate that montmorillonite is much weaker than illite (Moore and Lockner 2004; Morrow et al. 1992). Additionally, the frictional strength of physical mixtures of smectite and illite was tested by Morrow et al. (1992). They found that mixtures had frictional strengths intermediate to typical values for montmorillonite and illite. The frictional properties of natural mixed layer I-S have not been tested, however, and may prove to be different than a physical mixture of the two clays. The mixed layer I-S documented in this study, by Solum et al. (2005) and Vrolijk and van-der Pluijm (1999) suggest that further experimental work should be conducted to address the properties of this clay type.

\section{CONCLUSIONS}

We examine and compare core data and field samples from nine study sites along the Chelungpu fault, Taiwan. We show that the northern section of the Chelungpu fault that ruptured in the hanging wall of the old Chelungpu fault/Sanyi fault has less intense damage surrounding the fault core, a systematic geochemical and mineralogical trend across fault components, and most slip localized to a single slip surface. The southern Chelungpu fault is more intensely damaged with more complex geochemistry and mineralogy, and numerous faults that have developed a fault core and have probably accommodated slip over a dispersed area.

We show that, although smectite is absent or reduced abundance in the fault core at shallow depths of 200 to $1200+\mathrm{m}$, it is abundant in the fault core and present in some secondary fault gouge of the exhumed portion of the Chelungpu fault. The fault core has undergone a retrograde reaction of illite to smectite at the near surface and surface portions of the fault. This reaction is facilitated by surficial weathering processes, but possibly also by seismic energy and fluid flux in the fault core while the fault is seismically active. The mineralogical variations are important to document because they have significant implications on how the fault reaches the earth's surface. Major conclusions of this study are:

(1) The northern section of the Chelungpu fault may be a proxy for a young thrust fault ( 45 - $100 \mathrm{Ka}$ old), whereas the southern Chelungpu fault shows the progression into a more mature fault zone ( 1 Ma old).

(2) An increase in damage along the southern Chelungpu fault relative to the northern Chelungpu fault correlates with decreased co-seismic slip and increasing strong ground motion in 1999. The wide damage zone (up to $70 \mathrm{~m}$ ) and multiple slip surfaces in the southern Chelungpu fault zone indicate that seismic energy is dispersed across a wider zone, and may account for the decrease in slip along this section of the fault (Heermance et al. 2003). 
(3) Smectite in fault gouge at the surface is not due entirely to surficial weathering, but may also influenced by fault-related processes.

(4) Clay reactions may a complex role in how a fault reaches the free surface. Models assuming that smectite to illite reaction take place due to burial temperatures alone are oversimplified.

(5) Mixed layer illite-smectite clay needs to be tested for frictional strength, as it may not have the same properties as a physical mixture of the two clays.

The Chelungpu fault provides a valuable opportunity to study shale and clay-rich fault zones. Data presented in this work provide an important characterization of the along-strike and down-dip variations of the near surface and exhumed portions of the Chelungpu fault. These types of data are essential for the understanding of fluid flow properties and energy distribution of shale and clay-rich faults zones.

Acknowledgements Financial support for this work comes from a DOSECC student internship, a student grant from the American Association of Petroleum Geologists, a National Science Foundation Research Experience for Undergraduates grant, and Eastern Asia Pacific Summer Institute (EAPSI) grant from the National Science Foundation to Angela Isaacs. Many thanks are extended to Li-Wei Kuo and Shao-Yi Hung for field and logistical assistance in Taiwan. Thanks to Jih-Hao Huang and Hidemi Tanaka for providing insight during discussions regarding the Chelungpu fault and the 1999 earthquake.

\section{REFERENCES}

Abercrombie, H. J., I. E. Hutcheon, J. D. Bloch, and P. de-Caritat, 1994: Silica activity and the smectite-illite reaction. Geology, 22, 539-542.

Brace, W. F., and J. D. Byerlee, 1966: Stick-slip as a mechanism for earthquakes. Science, 153, 990-992.

Caine, J. S., J. P. Evans, and C. B. Forster, 1996: Fault zone architecture and permeability structure. Geology, 24, 1025-1028.

Caine, J. S., and C. B. Forster, 1999: Fault zone architecture and fluid flow: insights from fluid flow and modeling. In: Haneberg, W. C., P. S. Mozley, J. C. Moore, and L. B. Goodwin (Eds.), Am. Geophys. Mono., 113, 101-127.

Chen, C. H., and C. C. Lin, 1999: Surface ruptures along the Chelungpu fault during the ChiChi earthquake, Taiwan, Central Geologic Survey, Ministry of Economic Affairs, ROC, scale $1: 25000$.

Chen, W., and H. Kao, 2000: The Chi-Chi Earthquake Sequence of 1999: Dual, out-of-sequence thrust faulting in Taiwan, in International Workshop on Annual Commemoration of Chi-Chi Earthquake, Taiwain, 18-20 September, 2000, 71-81.

Chen, Y. G., W. S. Chen, J. C. Lee, Y. H. Lee, C. T. Lee, H. C. Chang, and H. C. Lo, 2001: Surface rupture of 1999 Chi-Chi earthquake yields insights on active tectonics ofcentral Taiwan. Bull. Seismol. Soc. Am., 91, 977-985. 
Chester, F. M., and J. M. Logan, 1986: Implications for mechanical properties of brittle faults from observation of the Punchbowl fault zone, California. Pure. Appl. Geophys., 124, 79-106.

Chester, F. M., J. P. Evans, and R. L. Biegel, 1993: Internal structure and weakening mechanisms of the San Andreas Fault. J. Geophys. Res., 98, 771-786.

Chester, F. M., J. M. Chester, D. L. Kirschner, S. E. Schulz, and J. P. Evans, 2004: Structure of large-displacement, strike-slip fault zones in the brittle continental crust. In: Karner, G. D., J. D. Morris, N. W. Driscoll, and E. A. Silver (Eds.), Rheology and Deformation of the Lithosphere at Continental Margins, Columbia University Press, New York, 223-260.

Chui, H. T., 1971: Folds in the northern half of western Taiwan. Petrol. Geol. Taiwan, 8, 7-19.

Covey, M.,1984: Lithofacies analysis and basin reconstruction, Plio-Pleistocene Western Taiwan foredeep. Petrol. Geol. Taiwan, 20, 53-83.

Dalguer, L. A., J. D. Irikura, J. D. Riera, and H. C. Chiu, 2001: The importance of the dynamic source effects on strong ground motion during the 1999 Chi-Chi, Taiwan, earthquake: brief interpretation of the damage distribution on buildings. Bull. Seismol. Soc. Am., 91, 1112-1127.

Evans, J. P., and F. M. Chester,1995: Fluid-rock interaction in faults of the San Andreas system: Inferences from San Gabriel fault rock geochemistry and microstructures. $J$. Geophys. Res., 100, 13007-13020.

Freed, R. L., and D. R. Peacor, 1989: Variability in temperature of the smectite/illite reaction in Gulf Coast sediments. Clay Miner., 24, 171-180.

Goddard, J. V., and J. P. Evans, 1995: Chemical changes and fluid-rock interaction in faults of crystalline thrust sheets, northwestern Wyoming, USA. J. Struc. Geol., 17, 533-547.

Heermance, R. V., 2002: Geometry and physical properties of the Chelungpu fault, Taiwan, and their effect on fault rupture. Master Thesis, Utah State Univ., Logan, Utah, USA.

Heermance, R. V., Z. K. Shipton, and J. P. Evans, 2003: Fault structure control on fault slip and ground motion during the 1999 rupture of the Chelungpu fault, Taiwan. Bull. Seismol. Soc. Am., 93, 1034-1050.

Hirono, T., and eleven others, 2006: Evidence of frictional melting from disk-shaped black material discovered within the Taiwan Chelungpu fault system. Geophys. Res. Lett., 33, L19311, doi:10.1029/2006GL027329.

Ho, C. S., 1975: An introduction to the geology of Taiwan-explanatory text of the geologic map of Taiwan, Central Geol. Survey, Ministry of Economic Affairs, ROC, 153 pp.

Ho, H. C., and M. M. Chen, 2000: The geologic map and explanatory text of Taichung, Taiwan, sheet 24, Central Geologic Survey, Ministry of Economic Affairs, ROC, scale 1 : 50000.

Hubbert, M. K., and W. W. Rubey, 1959: Role of fluid pressure in the mechanics of overthrust faulting. Bull. Geol. Soc. Am., 70, 115-166.

Hung, J. H., and D. V. Wiltschko, 1993: Structure and kinematics of arcuate thrust faults in the Miaoli-Cholan area of western Taiwan. Petrol. Geol. Taiwan, 28, 59-96.

Hung, J., and K. Ma, 2006: Structure geology, physical properties, fault zone characteristics and stress state in scientific drill holes of the Taiwan Chelungpu-fault Drilling Project, EOS Trans. AGU, 87, Fall Meet. Suppl. Abstract T21D-0454.

Hung, J. H., Y. H. Wu, E. C. Yeh, J. C. Wu, and TCDP Scientific Party, 2007: Subsurface 
structure, physical properties, and fault zone characteristics in the scientific drill holes of Taiwan Chelungpu-fault Drilling Project. Terr. Atmos. Ocean. Sci., 18, 271-293, doi: 10.3319/TAO.2007.18.2.271(TCDP).

Hyndman, R. D., 2004: Controls on subduction thrust earthquakes: downdip changes in composition and state, in Rheology and Deformation of the Lithosphere at Continental Margins. In: Karner, G. D., B. Taylor, N. W. Driscoll, and D. L. Kohlstedt (Eds.), Columbia University Press, New York, New York, 166-178.

Ide, S., and G. C. Beroza, 2001: Does apparent stress vary with earthquake size? Geophys. Res. Lett., 28, 3349-3352.

Jacobs, J., J. P. Evans, and P. T. Kolesar, 2006: Energetics of chemical alteration in fault zones and its relationship to the seismic cycle. In: Abercrombie, R., A. McGarr, H. Kanamori, and G. di Toro (Eds.), Earthquakes: Radiated Energy and the Physics of Faulting. Am. Geoph. Un. Geophy. Mono., 170, 181-192.

Johnson, K. M., Y.J. Hsu, P. Segall, and S. B. Yu, 2001: Fault geometry and slip distribution of the 1999 Chi-Chi, Taiwan earthquake imaged from inversion of GPS data. Geophys. Res. Lett., 28, 2285-2288.

Johnson, K. M., and P. Segall, 2004: Imaging the ramp-decollement geometry of the Chelungpu fault using coseismic GPS displacements from the 1999 Chi-Chi, Taiwan earthquake. Tectonophysics, 378, 123-139.

Kao, H., and W. Chen, 2000: The Chi-Chi earthquake sequence; active, out-of-sequecen thrust faulting in Taiwan. Science, 228, 2346-2349.

Kuan, M. Y., 1964: Clay mineral stain test of the subsurface formations in the Chinshui gas field, Miaoli, Taiwan. Petrol. Geol. Taiwan, 3, 141-149.

Lee, J. C., Y. G. Chen, K. Sieh, K. Mueller, W. S. Chen, H. T. Chu, Y. C. Chan, C. Rubin, and R. Yates, 2001: A vertical exposure of the 1999 surface rupture of the Chelungpu fault at Wufeng, western Taiwan: Structural and paleoseismic implications for an active thrust fault. Bull. Seismol. Soc. Am., 91, 914-929.

Lee, J. C., H. T. Chu, J. Angelier, Y. C. Chan, J. C. Hu, C. Y. Lu, and R. J. Rau, 2002: Geometry and structure of northern surface ruptures of the $1999 \mathrm{M}_{\mathrm{w}}=7.6$ Chi-Chi, Taiwan, earthquake: influence from inherited fold belt structures. J. Struc. Geol., 24, 173-192.

Liao, C. F., 2003: Analysis of fault rock deformation and clay minerals from fault cores of Chelungpu fault zone. Master Thesis, Natl. Taiwan Univ., Taipei, Taiwan, ROC.

Lin, C. H., 2000: Thermal modeling of continental subduction and exhumation constrained by heat flow and seismicity in Taiwan. Tectonophysics, 324, 189-201.

Lin, A., T. Ouchi, A. Chen, and T. Maruyama, 2001: Co-seismic displacements, folding and shortening structures along the Chelungpu surface rupture zone occurred during the 1999 Chi-Chi, Taiwan earthquake. Tectonophyics, 330, 225-244.

Lin, A., C. T. Lee, T. Maruyama, and A. Chen, 2005: Meso- and microstructural analysis of coseismic shear zone of the $1999 \mathrm{M}_{\mathrm{w}}$ 7.6 Chi-Chi earthquake, Taiwan. Bull. Seismol. Soc. Am., 95, 486-501.

Lin, A. T., S. M. Wang, J. H. Hung, M. S. Wu, and C. S. Liu, 2007: Lithostratigraphy of the Taiwan Chelungpu-fault Drilling Project-A borehole and its neighboring region, central Taiwan. Terr. Atmos. Ocean. Sci., 18, 223-241, doi: 10.3319/TAO.2007.18.2.223 (TCDP). 
Lockner, D. A., and N. M. Beeler, 2002: Rock failure and earthquakes, in International Handbook of Earthquake Engineering Seismology. In: Lee, W. H. K., H. Kanamori, P. C. Jennings, and C. Kisslinger (Eds.), Academic Press, San Diego, California, 505-533.

Lu, C. B., 2004: Fluid infiltration after seismic faulting: examining chemical and mineralogical composition of the fault rocks in the drilling cores from Nantou well of the Chelungpu fault. Master Thesis, Natl. Centl. Univ., Chung-Li, Taiwan, ROC. (in Chinese)

Ma, K. F., T. R. A. Song, S. J. Lee, and H. I. Wu, 2000: Spatial slip distribution of the September 20, 1999, Chi-Chi, Taiwan, earthquake, $\mathbf{M}_{\mathrm{w}} 7.6$ - Inverted from teleseismic data. Geophys. Res. Lett., 27, 3417-3420.

Moore, D. M., and R. C. Reynolds Jr., 1997: Individual Clay Minerals, X-ray Diffraction and the Identification and Analysis of Clay Minerals, Oxford University Press, New York.

Moore, D., and D. Lockner, 2004, Interpreting the frictional behavior of the smectite clay montmorillonite. EOS Trans. AGU, 85, Fall Meet. Suppl., T41F-1306.

Morrow, C. A., B. Radney, and J. Byerlee, 1992: Frictional strength and the effective pressure law of montmorillonite and illite clays, in Fault Mechanics and Transport Properties of Rocks, Academic Press, Ltd..

Ogelsby, D. D., and S. M. Day, 2001: The effect of fault geometry on the 1999 Chi-Chi, Taiwan earthquake. Geophys. Res. Lett., 28, 1831-1834.

Ouchi, T., A. Lin, A. Chen, and T. Maruyama, 2001: The 1999 Chi-Chi (Taiwan) earthquake: earthquake fault and strong ground motions. Bull. Seismol. Soc. Am., 91, 966-976.

Reynolds Jr., R. C., and R. C. Reynolds III, 1996: NEWMODTM, a computer program for the calculation of one-dimensional diffraction patterns of mixed-layered clays, http://www. angelfire.com/md/newmod/.

Schleicher, A. M., B. A. van der Pluijm, J. G. Solum, and L. N. Warr, 2006: Origin and significance of clay-coated fractures in mudrock fragments of the SAFOD borehole, (Parkfield, California). Geophys. Res. Lett., 33, L16313.

Scholle, P. A., 1978: A color illustrated guide to carbonate rock constituents, textures, cements, and porosities, Memoir 27, Am. Assoc. Petrol. Geol., Tulsa, Oklahoma.

Scholz, C. H., 1989: Mechanics of faulting. Ann. Rev. Earth Planet. Sci., 17, 309-334.

Schulz, S. E., and J. P. Evans, 1998: Spatial variability in microscopic deformation and composition of the Punchbowl fault, Southern California: implications for mechanisms, fluid-rock interaction, and fault Morphology. Tectonophysics, 295, 223-244.

Shin, T. C., and T. Teng, 2001: An Overview of the 1999 Chi-Chi, Taiwan, earthquake. Bull. Seismol. Soc. Am., 91, 895-913.

Sibson, R. H., 1977: Fault rocks and fault mechanisms. J. Geol. Soc. Lond., 133, 191-213.

Solum, J. G., B. A. van der Pluijm, D. R. Peacor, and L. Warr, 2003: Influence of phyllosilicate mineral assemblages, fabrics, and fluids on the behavior of the Punchbowl Fault, Southern California. J. Geophys. Res., 108, doi: 10.1029/2002JB001781.

Solum, J. G., B. A. van-der Pluijm, C. M. Hall, and D. R. Peacor, 2005: Neocrystallization, fabrics and age of clay minerals from an exposure of the Moab Fault, Utah. J. Struc. Geol., 27, 1563-1576.

Solum, J. G., S. H. Hickman, D. A. Lockner, D. E. Moore, B. A. van-der Pluijm, A. J. Schleicher, and J. P. Evans, 2006: Mineralogical characterization of protolith and fault rocks from 
the SAFOD main hole. Geophys. Res. Lett., 33, L21314, doi:10.1029/2006GL027285.

Sone, H., H. Shimamoto, S. Noda, K. Ma, Song, J. Hung, and C. Wang, 2005: Frictional properties and permeability of fault rocks from Taiwan Chelungpu-fault Drilling Project and their implicatongs for high-velocity slip weakening, EOS Trans. AGU, 86, Fall Meet. Suppl., Abstract T43D-06.

Sone, H., E. C. Yeh, T. Nakaya, J. H. Hung, K. F. Ma, C. Y. Wang, S. R. Song, and T. Shimamoto, 2007: Mesoscopic structural observations of cores from the Chelungpu Fault System, Taiwan Chelungpu-fault Drilling Project Hole-A, Taiwan. Terr. Atmos. Ocean. Sci., 18, 359-377, doi: 10.3319/TAO.2007.18.2.359(TCDP).

Song, S. R., L. W. Kuo, E. C. Yeh, C. Y. Wang, J. H. Hung, and K. F. Ma, 2007: Characteristics of the lithology, fault-related rocks and fault zone structures in TCDP Hole-A. Terr. Atmos. Ocean. Sci., 18, 243-269, doi: 10.3319/TAO.2007.18.2.243(TCDP).

Spudich, P., and K. B. Olsen, 2001: Fault zone amplified waves as a possible seismic hazard along the Calaveras Fault in Central California. Geophys. Res. Lett., 28, 2533-2536.

Tanaka, H., C. Y. Wang, W. M. Chen, A. Sakaguchi, K. Ujiie, H. Ito, and M. Ando, 2002: Initial science report of shallow drilling penetrating into the Chelungpu fault zone, Taiwan. Terr. Atmos. Ocean. Sci., 13, 227-251.

Vrolijk, P. J., and B. A. van der Pluijm, 1999: Clay Gouge. J. Struct. Geol., 21, 1039-1048.

Wang, C. Y., C. L. Lee, M. C. Wu, and M. L. Ger, 2007: Investigating the TCDP drill site using deep and shallow reflection seismics. Terr. Atmos. Ocean. Sci., 18, 129-141, doi: 10.3319/TAO.2007.18.2.129(TCDP).

Whitney, G., 1990: Role of water in the smectite-to-illite reaction. Clay Miner., 38, 343-350.

Wilson, J. E., J. S. Chester, and F. M. Chester, 2003: Microfracture analysis of fault growth and wear processes, Punchbowl fault, San Andreas system, California. J. Struct. Geol., 25, 1855-1873.

Wintsch, R. P., R. Christopherson, and A. K. Kronenberg, 1995: Fluid-rock reaction weakening of fault zones. J. Geophys. Res., 100, 13021-13032.

Wu, F. T., 1978: Mineralogy and physical nature of clay gouge. Pure Appl. Geophys., 116, 655-689.

Wu, J., S. Huang, M. Wang, C. Tsai, W. Mei, J. Hung, T. Lee, and K. Yang, 2005: Microfossil analysis of wells in the Chelungpu fault Zone Taiwan, AGU, Fall Meeting 2005, Abstract T51A-1331.

Wu, J. C., S. T. Huang, M. H. Wang, C. C. Tsai, W. W. Mei, J. H. Hung, T. Y. Lee, K. M. Yang, and K. F. Lee, 2007: Core slabbing and nannofossil analysis on the Chelungpu fault zone, Taichung, Taiwan. Terr. Atmos. Ocean. Sci., 18, 295-325, doi: 10.3319/ TAO.2007.18.2.295(TCDP).

Zhao, G., D. R. Peacor, and S. D. McDowell, 1999: "Retrograde Diagenesis" of clay minerals in the Precambrian Freda sandstone, Wisconsin. Clay Clay Miner., 47, 199-130.

Isaacs, A. J., J. P. Evans, S. R. Song, and P. T. Kolesar, 2007: Structural, mineralogical, and geochemical characterization of the Chelungpu thrust fault, Taiwan. Terr. Atmos. Ocean. Sci., 18, 183-221, doi: 10.3319/TAO.2007.18.2.183(TCDP). 